Witold Kulesza (Łódź)

\title{
Polska godność narodowa w świetle prawa karnego
}

\section{WSTĘP}

Polska jest współcześnie jedynym państwem w Europie, którego prawo przewiduje odpowiedzialność karną za publiczne znieważenie narodu lub okazywanie mu lekceważenia, co czyni godność narodową samoistnym dobrem prawnym. Wydaje się przeto wartą uwagi geneza przepisów chroniących to dobro prawne, wprowadzonych do polskiego prawa w 1932 r., a także potrzebny staje się komentarz do ustawowego opisu czynów godzących w nie, jak również ukazanie zagadnień powstających na gruncie praktycznego stosowania norm sankcjonujących w realiach współczesności. Chodzi bowiem o to, że teraźniejsze odczuwanie godności narodowej tkwi korzeniami w przeszłości i to właśnie historyczne doświadczenia wyznaczają kierunek wykładni przepisów obowiązującego prawa, chroniących godność narodu. Innymi słowy, dzisiejsza interpretacja norm prawnokarnych, zmierzająca do odpowiedzi na pytanie, jakie zachowania realizują znamiona sprawcze „lekceważenia” lub dalej idącego przejawu pogardy, jakim jest „znieważenie” polskiego narodu, oparta jest na pamięci zbiorowej i jako taka stanowi wykładnię historyczną, wiodącą do rozumienia normatywnej semantyki tych pojęć. Celem poniższych rozważań jest zatem spojrzenie na prawną współczesność przez pryzmat historycznie zdeterminowanej, symbolicznej kryminalizacji zachowań atakujących polską godność narodową i podanie przykładów współcześnie inkryminowanych publicznych wypowiedzi. Choć treść przepisów prawnokarnych statuujących odpowiedzialność karą za publiczne znieważenie i lekceważenie narodu nie uległa zmianie od czasu wprowadzenia ich do polskiego porządku prawnego, to jednak z tragicznej historii XX wieku i pamięci o niej wynikają współczesne oceny zachowań w kategoriach naruszeń godności narodu 
jako dobra prawnego. Badając takie konkretne zachowania, nieprzewidywalne przez przedwojennego ustawodawcę, podjąć trzeba próbę wskazania racji utrzymywania ich karalności.

\section{GODNOŚĆ NARODOWA JAKO PRZEDMIOT OCHRONY PRAWNOKARNEJ}

W systemie obowiązującego polskiego prawa karnego godność narodowa chroniona jest przed zachowaniami stanowiącymi przestępstwo opisane w art. 133 Kodeksu karnego $(\mathrm{KK})^{1}$, a także wykroczenie ujęte w treści art. 49 $\S 1$ Kodeksu wykroczeń $(\mathrm{KW})^{2}$. Na nasuwające się pytanie, czy przepisy te, będące swego rodzaju ewenementem w porównaniu do systemów prawa karnego innych państw Unii Europejskiej, w których godność narodowa ich obywateli nie jest przedmiotem ochrony, odpowiadają współczesnym założeniom racjonalnej kryminalizacji, ${ }^{3}$ poszukiwać trzeba odpowiedzi postrzegając tę kwestię z historycznej perspektywy. Jest tak dlatego, że kryminalizacja publicznie dokonywanych czynów godzących w narodową godność, uznanych przez ustawodawcę za przestępstwo znieważenia narodu i wykroczenie polegające na demonstracyjnym okazywaniu mu lekceważenia, datuje się od 1932 r., co sprawia, że wymagają uwzględnienia racje, na których opierało się ówczesne polskie prawo karne.

Uzasadnienie ustanowienia w art. 152 KK z 1932 r. odpowiedzialności tego, „kto publicznie lży lub wyszydza Naród albo Państwo Polskie”, przedstawił J. Makarewicz, zauważając, że ówczesne europejskie ustawodawstwo karne nie wprowadziło „ochrony narodu, jako synonimu ogółu narodowości obywateli da-

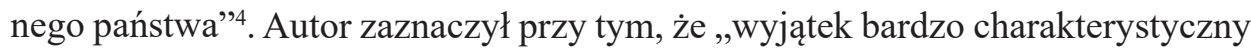
stanowi kodeks karny włoski z r. 1930, tzw. faszystowski; w art. 291 pomieszcza swoiste przestępstwo znieważenia, czy zohydzenia narodu włoskiego"s. J. Ma-

${ }^{1}$ Art. 133 KK: Kto publicznie znieważa Naród lub Rzeczpospolitą Polską, podlega karze pozbawienia wolności do lat 3 .

${ }^{2}$ Art. 49 § 1 KW: Kto w miejscu publicznym demonstracyjnie okazuje lekceważenie Narodowi Polskiemu, Rzeczypospolitej Polskiej lub jej konstytucyjnych organów podlega karze aresztu lub grzywny.

3 J. Kulesza, Problemy teorii kryminalizacji. Studium z zakresu prawa karnego i konstytucyjnego, Łódź 2017, s. 31 i n.

4 J. Makarewicz, Kodeks Karny z komentarzem, Lwów 1938, s. 403.

${ }^{5}$ Kodeks włoski, znany także jako „Codice Rocco” (od nazwiska ówczesnego ministra sprawiedliwości), opisywał przestępstwo określane jako Vilipendio alla nazione italiana słowami: „Kto publicznie znieważa włoski Naród, będzie ukarany więzieniem od jednego do trzech lat" (art. 291). Przepis art. 293 przewidywał, że kara za ten czyn ,zostanie podniesiona, jeżeli sprawca dopuścił się go zagranicą”. Odnotować trzeba, że karalność znieważenia narodu włoskiego ustanowiona została już wcześniej, w kodeksie karnym ministra sprawiedliwości Królestwa Włoch Zanardelliego z 1889 r. J. Makarewicz wskazywał na kodeks współczesny pracom nad polskim kodeksem karnym. 
karewicz przytoczył interpretację autentyczną tego przepisu, według której „fakt znieważenia narodu (La Nazione) nie dotyka Państwa w jego organicznym związku, ani też nie dotyka go w instytucjach zasadniczych, lecz dotyka ludności włoskiej (la popolazione italiana) niezależnie od tej konstytucji i jej politycznego organizmu, narusza się tutaj ideę, tak, jak przy znieważeniu sztandaru narusza się symbol"6. Ze swej strony nadawał Makarewicz włoskiemu pierwowzorowi dla art. 152 polskiego KK demokratyczną treść, pisząc: ,jasne jest, że kodeks faszystowski nie miał tu na myśli narodowości włoskiej, lecz ideę zwartego społeczeństwa obywateli włoskich niezależnie od rasowego pochodzenia, używanego języka, lub zabarwienia naskórka. Wyraźnie ustawodawca tłumaczy, iż wyraz Nazione jest identyczny z popolazione.” Dalej autor konstatował, że „nie ulega chyba

${ }^{6}$ J. Makarewicz, op.cit...., s. 404. Kodeks włoski opisywał szczegółowo przestępstwo znieważenia flagi w art. 292: „Kto narodową flagę albo godło państwowe znieważa będzie ukarany karą od jednego do trzech lat więzienia. W rozumieniu ustawy karnej narodową flagą jest urzędowa flaga państwowa i każda inna, która nosi barwy narodowe. Postanowienia tego artykułu znajdują zastosowanie do każdego, kto znieważa barwy narodowe, przedstawione jako flaga na innym przedmiocie". Surowszej karze podlegał obywatel, który zagranicą popełnił tak opisane przestępstwo (art. 293). W podsumowaniu raportu uzasadniającego wprowadzenie nowego kodeksu karnego oddającego ducha czasu napisał minister Rocco: „zarządzanie wymiarem sprawiedliwości w sprawach karnych, które ma naczelne znaczenie polityczne, będzie w coraz większym stopniu wnosić wkład do umocnienia państwa, bez którego nie istnieje ani bezpieczeństwo członków ludu, ani wielkość Narodu", cyt. za K. Bunge, Vorwort, Das Italienische Strafgesetzbuch vom 19. Oktober 1930. Sammlung Außerdeutscher Strafgesetzbücher. Nr. 50, Berlin und Leipzig 1933, s. 5. Polski KK z 1932 r. stanowił w art. 153: „Kto znieważa godło, chorągiew, banderę, flagę, sztandar lub inny polski znak państwowy, albo znak taki wystawiony publicznie uszkadza lub usuwa, podlega karze więzienia do lat 2 lub aresztu do lat 2”. J. Makarewicz zaznaczał, że „papierowe chorągiewki używane do przyozdabiania czyto lokali, czyto pochodów z okazji uroczystości nie podpadają pod kategorię tych godeł Państwa Polskiego, o których mowa w art. 153 k.k.” op.cit...., s. 406.

${ }^{7}$ Ibidem, s 404. Opublikowana w 1935 r. „Doktryna faszyzmu” zawierała zbiór tez wcześniej wygłaszanych przez B. Mussoliniego wyznaczających drogę ku przyszłości dla „wszystkich, którzy siłą natury lub historii starają się tworzyć lud Włoch (Popolo d'Italia) jako posiadający jedno sumienie i jedną wolę”. Nie chodzi przy tym - zaznaczał - „o rasę czy geograficznie określone otoczenie, lecz o wspólnotę, zbiorowość utrzymującą się razem, mającą równocześnie wolę istnienia i panowania, samoświadomość, osobowość.” B. Mussolini, Die Lehre des Faschismus, Firenze 1935, s. 18. Twierdzeniem tym różnił się w tym okresie włoski faszyzm od niemieckiego narodowego socjalizmu. O przynależności do rasy jako lepiszczu narodu wywodził A. Hitler: „,narodowość lepszej rasy leży bardziej w krwi aniżeli w języku” ponieważ „mieszanie krwi oznacza upadek poziomu rasy wyższej”. Głównym zagrożeniem dla wyższej rasy jest jej stopienie się z rasą niższą: „doświadczenia historyczne dostarczają nieskończoną liczbę przykładów (...) z szokującą wyrazistością ukazujących, iż z mieszania się krwi Aryjczyka z niższymi narodami wynika jego koniec jako nośnika kultury”. A. Hitler, Mein Kampf. Zwei Bände in einem Band, München 1944, s. 313, 426. Twierdzenia Hitlera o zagrożeniach dla rasy aryjskich germanów stanowiły podstawę dla ustaw norymberskich z 1935 r. (pozbawiających Żydów obywatelstwa i zakazujących małżeństw z Niemcami), we Włoszech podobne ustawy zostały wprowadzone w 1938 r. Szerzej W. Kulesza, Karanie za zbrodnię ,, zhańbienia rasy” (Rassenschande) i odpowiedzialność karna sędziów za zbrodnicze 
żadnej wątpliwości, iż chodzi tutaj o ochronę społeczeństwa, złożonego z obywateli państwa, bez różnicy czynnika etnicznego". Wiodło to do sformułowania komentarza, według którego, na wzór włoskiego, również polski KK rozumie pod pojęciem narodu wszystkie jego „pierwiastki etniczne”, z których społeczeństwo polskie się składa. W ten sposób ustanowiona została ochrona godności narodu jako obejmującego wszystkich obywateli państwa, w którym $1 / 3$ z nich była innej narodowości niż polska (Żydzi, Ukraińcy) ${ }^{8}$. W świetle takiej wykładni karalnymi na gruncie polskiego prawa miały być $m$. in. publiczne wypowiedzi, takie jak: „Polska jest krainą bandytów”, „Polska to kraina lichwiarzy, oszustów i handlarzy żywym towarem”, gdyż obrażają całe polskie społeczeństwo9. Podobnie „obelgi na temat polnische Wirtschaft (...), w których przymiotnik "polski« wiązać się będzie z określeniami zaczerpniętymi z zoologii, nawet w tym wypadku, mieć będziemy do czynienia z obrazą całego społeczeństwa polskiego, a nie tylko narodowości polskiej." ${ }^{\prime 10}$ Autor zaznaczał, że zadaniem sędziego jest ustalenie, czy zamiar sprawcy skierowany był na obrażenie społeczeństwa polskiego jako całości, tworzącej fundament dla prawno-państwowej konstrukcji, czy też chodziło o dotknięcie danej jednostki, lub choćby jakiejś grupy jednostek, do której należy znieważona jednostka. Jeżeli sprawca dodaje do nazwy danej narodowości soczyste epitety - wywodził cytowany autor - to będziemy mieli do czynienia tylko z przestępstwem z art. $256 \mathrm{KK}$ (znieważenia osoby), tj. obrazy godności osobistej danej osoby, która do tej narodowości należy, choćby była to narodowość polska, nie zaś ze znieważeniem całego narodu polskiego, w rozumieniu art. $152 \mathrm{KK}^{11}$.

Sąd Najwyższy odniósł się, w wyroku z 17.05.1934 r., ${ }^{12}$ krytycznie do zarzutu uzasadniającego skargę kasacyjną, w której podniesiono, że „lżenie słowami "polnisches Schwein«" nie stanowi przestępstwa z art. $152 \mathrm{KK}$ ponieważ „słowa te nie odnosiły się do Narodu lub Państwa Polskiego jako całości, lecz tylko do poszczególnych członków Narodu Polskiego". SN skonstatował jednakże, iż słowa te, użyte wobec trzech osób, „odnosiły się nie tylko do tych osób, lecz do całego Narodu Polskiego, i że oskarżeni działali w zamiarze zelżenia polskości i każdego Polaka, a więc w sumie całego Narodu Polskiego". Sformułowana została następnie teza, według której „okoliczność, że czyn zawiera również cechy

skazania [w:] Nauki penalne wobec szybkich przemian socjokulturowych. Ksiega jubileuszowa Profesora Mariana Filara, red. A. Adamski, J. Bojarski, P. Chrzczonowicz, M. Leciak, t. I, Torun 2012, s. 367.

8 J. Makarewicz, op.cit., s. 405.

${ }^{9}$ Ibidem, s. 405.

${ }^{10}$ Ibidem, s. 405.

${ }^{11}$ Ibidem.

${ }^{12}$ Sygn. akt 3 K. 369/34, Zbór orzeczeń Sądu Najwyższego. Orzeczenia Izby Karnej 1934, z. I, poz. 281. 
obrazy osobistej, nie wyłącza możliwości równoczesnego istnienia cech zniewagi Narodu Polskiego i istnienia u sprawcy zamiaru skierowanego na popełnienie zarówno zniewagi osobistej, jako też zniewagi Narodu Polskiego".

W polskim KK z 1932 r. przyjęcie za wzór ochrony narodu przed znieważeniem, ustanowionej w jego art. 152, koncepcji, na której opierał się art. 291 włoskiego KK z 1930 r. różniło się zasadniczo od rozwiązań postulowanych w doktrynie narodowosocjalistycznych Niemiec i wprowadzonych w 1933 r. do niemieckiego Kodeksu Karnego (StGB), które pozwalały na drakońskie karanie wszelkich wypowiedzi, uznanych za szkodzące narodowi niemieckiemu ${ }^{13}$.

13 Jako podstawę prawną dla skazań za wypowiedzi uznane za szkodzące narodowi niemieckiemu powoływano w III Rzeszy ustawę z 20.12.1934 r. „przeciwko zdradzieckim zamachom na Państwo i Partię oraz ochronie uniformów partyjnych" (Heimtückegesetz), która ustanowiła karalność wszelkich zamierzonych, nieprawdziwych lub choćby lekkomyślnych, publicznych, jak i niepublicznych (jeżeli sprawca liczył się z ich dalszym rozpowszechnieniem) złośliwych wypowiedzi o faktach mogących zaszkodzić wizerunkowi rządu Rzeszy lub stojącej za nim NSDAP. Przepis $\S 90 f$ StGB przewidywał karę ciężkiego więzienia dla sprawcy zdrady narodu (Volksverrat) tj. tego, „kto publicznie lub jako Niemiec za granicą sprowadza poważne zagrożenie dla poważania niemieckiego Narodu poprzez nieprawdziwe lub ordynarnie uwłaczające twierdzenia natury faktycznej”. Przepis uzasadniano koniecznością ochrony czci narodu niemieckiego przed zamachami, ponieważ jest to elementarny warunek narodowego samoposzanowania i narodowej samoświadomości”. Das kommende deutsche Strafrecht. Besonderer Teil. Bericht über die Arbeit der amtlichen Strafrechtskommision, Hrsg. F. Gürtner, Berlin 1936, s. 98-100. Za podstawę karania za wypowiedzi znieważające Niemców przyjmowano także przepis $\S 134 \mathrm{a}$ StGB chroniący państwo - Rzeszę, który nie wymieniał jednakże osobno niemieckiego narodu jako mającego podlegać ochronie przed obrazą. W drodze wykładni przyjęto, że pojęcie Rzesza (Reich) oznacza także naród (Volk), gdyż oba pojęcia pozostają w ścisłym związku. Niemiecki sąd specjalny (Sondergericht) w Łodzi skazał w 1942 r. na podstawie tego przepisu na rok i 6 miesięcy więzienia Folksdojcza, który będąc pijanym, mówił na ulicy miasta o „tych przeklętych Szwabach” (,die verfluchten Schwaben”). W uzasadnieniu skazania odwołano się do orzecznictwa sądowego, według którego § 134a StGB, choć wyraźnie wymienia tylko Rzeszę (Reich) jako całość organizmu państwowego, to chroni także naród (Volk), bez którego państwo ,jest nie do pomyślenia”. H. Schlüter, „... für die Menschlichkeit im Srafmaß bekannt...". Das Sondergericht Litzmannstadt und sein Vorsitzender Richter, Juristische Zeitgeschichte NRW. Band 14, Recklinghausen 2007. s. 115. Zob. także W. Kulesza, Sąd Specjalny (Sondergericht) w Łodzi, [w:] Gmach i jego tajemnice. Sąd Okręgowy w Lodzi 1917-2017, Łódź 2017, s. 67-69.

Niczym nieograniczone możliwości posługiwania się przez niemieckich sędziów karą śmierci za wszelkie zachowania uznane za szkodzące niemieckiemu narodowi stworzone zostały przez przepis ust. I pkt. 3 rozporządzenia „,o postępowaniu karnym przeciwko Polakom i Żydom na włączonych terenach wschodnich” (Polenstrafrechtsverordnung) z 4.12.1941 r.: „oni [Polacy i Żydzi] będą karani śmiercią, a w mniej ciężkich przypadkach karą pozbawienia wolności, jeżeli przez nienawistną lub podburzającą działalność wykazują wrogą wobec Niemców postawę, w szczególności wyrażają się wrogo o Niemcach, zdzierają lub uszkadzają publiczne obwieszczenia niemieckich władz lub służb, albo jeżeli przez swoje inne zachowania obniżają lub szkodzą poważaniu lub dobru Rzeszy niemieckiej lub niemieckiego Narodu”. Szerzej W. Kulesza, Crimen laesae iustitiae. Odpowiedzialność karna sędziów i prokuratorów za zbrodnie sądowe wedlug prawa norymberskiego, niemieckiego, austriackiego i polskiego, Łódź 2013, s. 115. 


\section{NARÓD A PAŃSTWO WEDŁUG WŁOSKIEGO FASZYZMU}

Uzasadnienie dla skorzystania przez J. Makarewicza z włoskiego wzoru w zakresie prawnokarnej ochrony narodu przed publicznym znieważeniem nie odwoływało się do natury włoskiego faszyzmu, dlatego potrzebne jest zwrócenie uwagi na to, że jej istotą było postawienie, w hierarchii dóbr prawnych, państwa przed narodem, które miało być pierwotne w stosunku do zastanego społeczeństwa i to dopiero państwo, przez swą moc we władczym działaniu, miało stworzyć naród włoski, w kształcie pożądanym przez władzę.

Oceniając włoski KK pisał R. Lemkin, że ,projekt faszystowski zgodnie z apoteozą państwa, stanowiącą jeden z punktów programowych faszyzmu, użycza nader wydatnej ochrony państwu. Chronione jest państwo nie tylko jako twór prawny, jako pewna terytorialnie zamknięta całość, lecz również użyczona jest szeroka ochrona potencjalnym siłom państwa jego rozwojowi i rozrostowi"14. Choć kodeks nie ustanowił, obok karalności znieważenia narodu włoskiego, odpowiedzialności za znieważenie samego państwa ${ }^{15}$, to równocześnie surową karą groził za publiczne znieważenie jego instytucji, wśród których wymieniał Wielką Radę Faszystowską ${ }^{16}$. Przepisy tego kodeksu odzwierciedlały poglądy B. Mussoliniego, który absolutyzował państwo i twierdził kategorycznie, że „to nie lud, jak wcześniej przyjmowano, tworzy państwo, lecz przeciwnie, państwo wytwarza naród jako moralną jedność świadomego swej woli ludu, a w następstwie rzeczywiste jego istnienie"17. Prymat państwa nad narodem wyrażał głosząc: „państwo troszczy się o wewnętrzne i zewnętrzne bezpieczeństwo, ale jest także stróżem i nosicielem ducha narodu, który z biegiem stuleci kształtował się w języku, zwyczajach i wierze"18. Faszyzm we Włoszech - tłumaczył - ,jest spirytualistyczną reakcją na senny materialistyczny pozytywizm XIX w."19 Jest on najodpowiedniejszą nauką, reprezentującą skłonności i stan ducha narodu, takiego jak naród włoski, który zmartwychwstał po długich

${ }^{14}$ R. Lemkin, Kodeks Karny Faszystowski, Warszawa 1929, s. 62. W przedmowie do tej publikacji pisał W. Makowski, że „koncepcje kodeksu karnego faszystowskiego są interesujące nie tylko jako jeden z projektów reformy ustawodawstwa karnego podobny do takich samych prób dokonywanych w innych państwach, ale także jako wyraz pewnych szczególnych tendencji ustroju faszystowskiego". Ibidem, s. 5.

${ }^{15}$ Ustanowiona została natomiast w art. 269 tego kodeksu karalność za zniesławienie państwa, którego dopuszczał się „obywatel włoski przekazujący lub szerzący za granicą fałszywe, przesadzone lub wypaczone pogłoski lub wiadomości o stosunkach wewnętrznych w państwie, mogących ograniczyć zaufanie lub szacunek" dla Włoch.

${ }^{16}$ Art. 290. Kto publicznie znieważa Koronę, królewski Rząd, Wielką Radę Faszystowską, Parlament lub tylko jedną z jego Izb będzie ukarany więzieniem od jednego do sześciu lat. Ta sama kara spotka każdego, kto publicznie znieważa siły zbrojne lub porządek sądowy.

17 B. Mussolini, Die Lehre..., s. 19.

${ }^{18}$ Ibidem, s. 46.

19 Ibidem, s. 11. 
stuleciach przymusu, któremu podlegał przez obce nad nim panowanie. W jednej ze swych głównych tez twierdził Mussolini, że: „faszyzm włoski nie jest tylko politycznym powstaniem przeciwko słabym i niezdarnym rządom, które pozwoliły na upadek autorytetu państwa i które groziły Włochom zahamowaniem na drodze ich rozwoju, jest on także duchowym powstaniem przeciwko starym doktrynom, jakie zniszczyły święte zasady religii, ojczyzny i rodziny. Faszyzm jest zatem bezpośrednim wyrazem narodu"20. Rozumowanie takie prowadziło do wniosku, że „państwo faszystowskie ma swoją własną samoświadomość i wolę, dlatego zasługuje na określenie go jako »państwo etyczne «"21. Zapewniał w swych wywodach, że: ,jedność wszystkich klas, polityczna, społeczna i moralna jedność narodu włoskiego urzeczywistnia się - w faszystowskim reżymie - w państwie, i tylko w faszystowskim państwie" 22 . Jest tak dlatego, że „to w państwie faszystowskim żyje duch narodu, który urzeczywistnia się poprzez urządzenia polityczne, prawne i gospodarcze, a przekraczając wąskie granice życia indywidualnego reprezentuje ono immanentne sumienie narodu" ${ }^{23}$. Z tego wynikało uzasadnienie dla zasady, według której to nie naród jako taki, lecz „to państwo, jako moralna wola powszechna, tworzy prawo"24. Twierdzenie, że to państwo tworzy naród i jego prawo jest fundamentem ideologii faszystowskiej i uzasadnieniem dla karania za zniewagę narodu jako własnego dzieła państwa.

Ponieważ państwo jest dla faszyzmu absolutem, relatywnego znaczenia nabierają $\mathrm{w}$ nim pojedynczy ludzie i ugrupowania. W państwie faszystowskim zapewniał cytowany autor - ,jednostka nie jest niszczona, raczej, tak jak w regimencie wojska nie jest pomniejszany żołnierz, lecz zwielokrotniony zostaje on przez liczbę towarzyszy broni”. Jednostkom takim faszystowskie państwo „pozostawia wystarczającą przestrzeń; ograniczyło ono niekonieczne i niebezpieczne wolności, lecz zachowało wolności istotne" 25 . Generalnie, w obszarze tego, co wolno, decyduje samo państwo, nie zaś jednostka. Dlatego państwo żąda dyscypliny, zebrania razem wszystkich sił i wykonywania obowiązków. To właśnie „wyjaśnia wielorakie formy praktycznej działalności rządu i konieczną surowość wobec każdego, kto chciałby się przeciwstawić temu spontanicznemu i pełnemu wykonawczej woli ruchowi Włoch XX wieku"26.

${ }^{20}$ Ibidem, s. 61.

${ }^{21}$ Ibidem, s. 45.

${ }^{22}$ Ibidem, s. 69.

${ }^{23}$ Ibidem, s. 45-46.

${ }^{24}$ Ibidem, s. 19.

${ }^{25}$ Ibidem, s. 50.

${ }^{26}$ Ibidem, s. 52-53. Art. 289 włoskiego KK groził karą ciężkiego więzienia „nie poniżej 10 lat, o ile nie chodzi o cięższą zbrodnię, każdemu, kto popełnia czyn „nacelowany choćby na częściowe lub okresowe przeszkodzenie (...) Wielkiej Radzie Faszystowskiej w wykonywaniu jej zadań”. 
Mussolini wyznaczył relację faszyzmu do demokracji wywodząc: „można by demokratyczne reżymy określić następująco: w reżymie takim, od czasu do czasu, stwarza się narodowi iluzję panowania, podczas gdy rzeczywiste i skuteczne panowanie wynika z działania innych sił, często nieodpowiedzialnych i tajnych"27. Faszyzm natomiast jest - deklarował - „demokracją, która sprzeciwia się poniżającemu sprowadzeniu narodu do gołej większości i dlatego jest najczystszą formą demokracji” ${ }^{28}$. Faszyzm „nie jest tylko systemem rządzenia, lecz także, i przede wszystkim, systemem myślenia”29. Faszyzm „pojmuje naród jakościowo, a nie kwantytatywnie, co oznacza urzeczywistnienie w interesie wszystkich sumienia i woli władczej nielicznych lub jednostki najmoralniejszej i najroztropniejszej"30. Dlatego faszystowskie państwo, jest „zorganizowaną, zcentralizowaną, autorytarną demokracją”, która „odrzuca konwencjonalne kłamstwo o równości politycznej, stan zbiorowej nieodpowiedzialności i mit szczęścia”" ${ }^{\text {11 }}$.

Przyszłość narodu włoskiego wyznaczał Mussolini wywodząc, że „faszyzm jest nauką życia, która wytwarza wiarę, opanowującą dusze, gdyż ma on swoich zmarłych i męczenników, a tysiąc znaków wskazuje, że jest to nauka obecnego stulecia”. Faszystowskie państwo „to nie tylko współczesność, lecz przede wszystkim przyszłość". Koniecznością świadomego swych zadań państwa, reprezentującego postępowy naród, jest dokonanie zmiany jego fizycznego wyglądu. Państwo „musi wypowiedzieć wobec narodu wielkie słowa, przedstawić mu wielkie idee i postawić wielkie zadania i nie może zajmować się tylko gołym administrowaniem" ${ }^{32}$. Faszyzm w swej myśli przewodniej „potępia pacyfizm jako ucieczkę przed wojną, tchórzostwo wobec potrzeby ofiarności”. Czyni to dlatego, że „tylko wojna napina wszystkie ludzkie siły i uszlachetnia narody, które się na nią odważą. Walka jest początkiem każdego bytu i pozostaje stale podstawą ludzkiej natury jako nieunikniona zależność"33.

Przytoczenie głównych tez Mussoliniego wymaga równoczesnego dodania na marginesie rozważań - że według obowiązującego współcześnie polskiego prawa czyn tego, „kto publicznie propaguje faszystowski lub inny totalitarny ustrój państwa" stanowi przestępstwo z art. $256 \S 1 \mathrm{KK}$ zagrożone karą pozba-

${ }^{27}$ B. Mussolini, Die Lehre..., s. 36.

28 Ibidem, s. 18.

${ }^{29}$ Ibidem, s. 14

${ }^{30}$ O przywódcy „najmoralnieszym” wywodził A. Hitler pisząc, że demokratycznie wybrane władze Republiki Weimarskiej to „kanalie (Kanalien), które wyprzedały cały kraj”, a jej „rząd sam jest zdrajcą kraju wolnym od wszelkiej kary”. Głosząc, że pewnego dnia „objawi się uczciwy idealista (der redlische Idealist)” pytał, czy powinno się pozwolić, aby „zdradziecka mała kreatura była znowu usuwana przez kreaturę czy przez idealistę". Mein Kampf..., s. 610.

31 B. Mussolini, Die Lehre..., s. 39.

${ }^{32}$ Ibidem, s. 68.

${ }^{33}$ Ibidem, s. 62. 
wienia wolności do lat 2. Zauważyć trzeba, że w następnym paragrafie przepis ten grozi taką samą karą temu, kto w celu rozpowszechnienia m.in. „przechowuje, posiada, prezentuje (...) druk" zawierający treść propagującą ustrój faszystowski” (art. $256 \S 2 \mathrm{KK}$ ). Kolejny paragraf nieracjonalnie nazywa „sprawcą czynu zabronionego" tego, kto dopuścił się czynu „w ramach działalności artystycznej, edukacyjnej, kolekcjonerskiej lub naukowej” stanowiąc, że w takich przypadkach „nie popełnia przestępstwa” (art. $256 \S 3 \mathrm{KK}$ ). Posiadający powoływaną powyżej „Moją walkę” Hitlera i „Doktrynę faszyzmu” Mussoliniego jest zatem normatywnie określony, jako „sprawca” zachowania prawnokarnie zakazanego, który tylko wyjątkowo „nie popełnia przestępstwa”, a przecież działalność naukowa, o którą chodzi w tym przepisie, z istoty swej nie atakuje żadnego dobra społecznego, prawem chronionego, ani też prowadzący ją nie ma zamiaru popełnienia czynu zabronionego. Nie jest przeto zrozumiałe stygmatyzowanie go przez ustawodawcę określeniem ,sprawca czynu zabronionego" ${ }^{34}$.

\section{LEKCEWAŻENIE NARODU POLSKIEGO JAKO CZYN ZABRONIONY}

Dla współczesnego komentatora przepisów chroniących polską godność narodową może nie być znaną geneza ustanowienia, (niejako dodatkowo, albowiem nie tylko w art. $152 \mathrm{KK}$ z 1932 r, lecz także w tym samym roku, w art. 18 Prawa o wykroczeniach) karalności demonstracyjnego okazywania publicznie lekceważenia Narodowi Polskiemu ${ }^{35}$. Ustanowiona w 1932 r. dwutorowa ochrona polskiej godności narodowej, na którą publiczny atak oceniany mógł być jako przestępstwo „znieważenia” lub wykroczenie polegające na „demonstracyjnym lekceważeniu narodu", utrzymana została przez kodeks karny z 1969 r. ${ }^{36}$ oraz wykroczeń

\footnotetext{
${ }^{34}$ Szerzej W. Kulesza, Swastyka w świetle prawa karnego i zbiorowej pamięci, [w:] Inspiracje i kontynuacje. W kręgu idei Profesora Mariana Cielaka, red. W. Cieślak, Bydgoszcz-Gdańsk 2015, s. 104. W. Kulesza, Pochwalanie faszyzmu i komunizmu w świetle prawa karnego (Uwagi de lege praevia, lata et ferenda), [w:] Teoretyczne i praktyczne problemy współczesnego prawa karnego. Ksiegga jubileuszowa dedykowana Profesorowi Tadeuszowi Bojarskiemu, red. A. Michalska-Warias, I. Nowikowski, J. Piórkowska-Flieger, Lublin 2011, s. 432. W. Kulesza, Propagowanie ideologii nazistowskiej lub jej symboliki ws świetle niemieckiego i polskiego prawa karnego, [w:] Zagadnienia teorii i nauczania prawa karnego. Kara łaczna. Księga Jubileuszowa Profesor Marii Szewczyk, red. W. Górowski, P. Kardas, T. Sroka, W. Wróbel, Warszawa 2013, s. 215-216.

${ }^{35}$ W. Kulesza, J. Kulesza, Lekceważenie a znieważenie Narodu Polskiego, Rzeczypospolitej Polskiej, jej Prezydenta lub konstytucyjnych organów - wykroczenie a przestepstwo, [w:] Na styku prawa karnego i prawa o wykroczeniach. Zagadnienia materialnoprawne i procesowe. Księga jubileuszowa dedykowana Profesorowi Markowi Bojarskiemu, red. J. Sawicki, K. Łucarz, t. 1, Wrocław 2016, s. 278.

${ }^{36}$ KK z 1969 r. stanowił w art. 270 § 1: „Kto publicznie lży, wyszydza lub poniża Naród Polski, Polską Rzeczpospolitą Ludową, jej ustrój lub naczelne organy podlega karze pozbawienia wolności
} 
z $1971 \mathrm{r} \cdot{ }^{37} \mathrm{i}$ taką pozostaje - jak podano na wstępie rozważań - w obowiązującym porządku prawnym ${ }^{38}$. Istotę wykroczenia ilustrował $\mathrm{J}$. Makarewicz następująco: „nazwanie Państwa Polskiego - państwem sezonowem jest oznaką lekceważenia państwa jako tworu nietrwałego" ${ }^{39}$. Autor miał na myśli zapewne określenie „kraj sezonowy”, którego po I wojnie światowej używano często w Niemczech dla wyrażenia przekonania, że Polska powstała jako krótkotrwały byt określony przedmiotowo przez przejściowo zaistniałe stosunki międzynarodowe. Ówcześni niemieccy politycy posługiwali się tym inkryminowanym, w świetle komentarza Makarewicza określeniem, dając wyraz traktowania polskiego społeczeństwa za trwale niezdolne do stworzenia i utrzymania własnej państwowości jako podmiotu prawa międzynarodowego. Główną przyczyną miały być nie tyle warunki historyczne, ile cechy polskiego charakteru narodowego, które szczegółowo przedstawił K. Loesch w wydanej w Berlinie w 1940 roku pracy Polski charakter narodowy. Opinie i samoświadectwa z czterech stuleci ${ }^{40}$. Książka ta stała się swego rodzaju podręcznikiem dla niemieckich funkcjonariuszy przybywających do okupowanej Polski, ukazującym właściwości pokonanego w wojnie społeczeństwa, nad którym mieli sprawować władzę. Główne tezy tej publikacji znalazły się w wypowiedziach gauleiterów i namiestników III Rzeszy A. Forstera, A. Greisera i generalnego gubernatora $H$. Franka, a także wielu niższych urzędników głoszących, że Polacy zasłużyli sobie na swój los bezwolnych niewolników i że Polska nigdy nie odrodzi się jako niepodległe państwo.

Autor powołanego wyżej opracowania o polskim charakterze narodowym rozpoczął swój wywód od stwierdzenia: „we wrześniu 1939 rozpadła się ta Polska, która jesienią 1918 natychmiast wstąpiła do frontu przeciwko całym Niemcom pomimo tego, że władczymi środkami stworzone zostały podstawy jej państwowości po podboju ziem polskich w $1915 \mathrm{r}$." ${ }^{41}$. W podsumowaniu natomiast napisano o Polakach: „każde z ich powstań było nieudane, ale nie powiodła się także próba zwrócenia im własnego państwa. Podstawowy feler ich duszy narodowej to doprowadzanie do buntu przeciwko każdemu porządkowi państwowemu, porządkowi obcemu, jak i własnemu porządkowi prawnemu, przez co uniemoż-

od 6 miesięcy do lat 8”. Komentarz do tego przepisu zob. W. Kulesza, [w:] System Prawa Karnego. O przestępstwach w szczególności, red. I. Andrejew, L. Kubicki, J. Waszczyński, t. IV, cz. 2, Wrocław-Lódź, 1989, s. 722 i n.

${ }^{37} \mathrm{KW}$ z $1971 \mathrm{r}$. głosił w art. 49 § 1, że podlega karze aresztu albo grzywny ten, „kto w miejscu publicznym demonstracyjnie okazuje lekceważenie dla Narodu Polskiego, Polskiej Rzeczpospolitej Ludowej, jej ustroju lub naczelnych organów".

${ }^{38}$ Zob. przypis 1 i 2.

39 J. Makarewicz, Kodeks Karny..., s. 674.

${ }^{40}$ K.C. v.Loesch, Der polnische Volkscharakter. Urteile und Selbstzeugnisse aus vier Jahrhunderten, Berlin 1940.

${ }^{41}$ Ibidem, s. 5. 
liwiają oni, by stali się Europejczykami w sensie określonym przez Talleyranda, co znaczy tylko tyle, by prowadzić własne życie w ustanowionym przez siebie ustawowym porządku" "22. Trwałe i niezmienne cechy polskiego społeczeństwa twierdził K. Loesch - ujawniły się ponownie po 1918 r., gdy powstało państwo polskie: „W odzyskanej państwowości nie uniknięto żadnego z wcześniejszych błędów, które doprowadziły do tego, że przez 150 lat naród polski nie miał własnego państwa. Polska została ponownie rozdarta przez kłótnie o kierunek i walki partyjne, ściślej przez targi klik o łup, którym stało się własne państwo, powstałe nagle, któremu jednak zabrakło lojalnych obywateli’³.

Konkluzję powyższą poprzedzają omówienia i cytaty zaczerpnięte z publikacji i wypowiedzi cudzoziemców, jak i samych Polaków, które zostały określone jako „naukowe”, świadczące o polskim charakterze narodowym, na który składają się takie ich cechy, jak:

- ,niedbalstwo. Tylko w czasie powszechnego wzbudzenia zdobywają się Polacy na dokładność w pracy i punktualność”, ${ }^{4}$

- „Polacy odmawiają czci i wiary każdemu, kto odważy się mieć inne zdanie aniżeli oni. Szastają na lewo i prawo jadowitymi epitetami i nazywają zdrajcą każdego, kto jest zwolennikiem przeciwnego obozu"; 45

- „Polak lubi krytykować innych, ale sam nie lubi być krytykowanym”;46

- „Polakom brakuje porządku, dyscypliny, punktualności, spostrzegawczości, zdolności do posłuszeństwa i wydawania rozkazów, poczucia obowiązku itd. (...) a także zdolności do doprowadzenia do końca realizacji jakiegokolwiek zamiaru" (opinia sformułowana na podstawie obserwacji 1100 polskich oficerów w czasie I wojny światowej ); ${ }^{47}$

- ,gadatliwość, kramarzenie słowami, rzucanie ich na wiatr. Nie ma drugiego takiego kraju, w którym mówi się tak wiele na wiatr, jak w Polsce. Obietnice i przyrzeczenia dawane są bez myślenia o ich dotrzymaniu, niedotrzymywanie słowa, chełpliwość" 48 .

Jako cechę polskiego narodowego charakteru wskazywano także i to, że: „ludzie robią wszystko tylko w połowie”, przy czym „brak im poczucia odpowiedzialności za sprawy gospodarcze i społeczne, natomiast planowanie znaczyło w Polsce niewiele więcej, aniżeli cel sam w sobie". Cytowano przy tym słowa

\footnotetext{
42 Ibidem, s. 94.

43 Ibidem, s. 86.

44 Ibidem, s. 80.

45 Ibidem.

46 Ibidem.

47 Ibidem, s. 79.

48 Ibidem, s. 41.
} 
byłego polskiego ministra finansów: „Polen sei ein Land der Fiktionen” ${ }^{\prime 49}$. Na zakończenie zestawione zostały w parach sprzeczności charakteru narodowego, które w swym natężeniu odróżniają Polaków od wszystkich innych narodów. Są to m.in. $\mathrm{z}$ jednej strony dalekowzroczne planowanie i talenty $\mathrm{w}$ wielu dziedzinach, a równocześnie $-\mathrm{z}$ drugiej strony - niekonsekwencja, bezwolne, hulaszcze postępowanie i polityczna wiara w cuda. Dalej: „dążenie do wolności, wyniosła duma i mania wielkości”, a równocześnie ,poczucie niższości, służalczość, uległość”. W kolejnym zestawieniu sprzeczności wymieniono „sięgające niebios porywy (uniesienia)" przy równoczesnym „powszechnym zniechęceniu”. Wskazano także na „gotowość do poświęceń, najdzielniejszą miłość do ojczyzny” i „ubóstwienie polskiego państwa”, a przy tym ,jaźń pożądająca rabowania państwa i dobra publicznego, ciemiężenie i ubezwłasnowolnienie członków własnego narodu, a także narodowo obcych." Wymienione zostały także jako pozostające w charakterologicznej sprzeczności Polaków skłonność do zdrady, tj. donosicielstwa do władz, określonego jako świadczenie „znacznych usług, gdy o porządek troszczą się narodowo im obcy” wobec „zawodności ich poczucia obowiązku przy samostanowieniu we własnym państwie”. Na końcu podkreślono, że „takie są przyczyny polskiej anarchii, która na swój sposób służy polskiej duszy”, a ta „złączona jest szczelnie z polskim językiem i tradycją"50.

W przedłożonym w 1946 r. Najwyższemu Trybunałowi Narodowemu akcie oskarżenia przeciwko najwyższemu urzędnikowi w tzw. Kraju Warty (Warthegau, tj. części okupowanej Polski włączonej do Rzeszy), jakim był Artur Greiser, napisano w jednym z punktów, że jego liczne publiczne wypowiedzi stanowiły przestępstwo z art. $152 \mathrm{KK}$, ponieważ „brał udział w lżeniu i wyszydzaniu Narodu Polskiego, głosząc jego niższość kulturową i małą wartość społeczną" ${ }^{1}$. Na uzasadnienie tego zarzutu cytowano w trakcie rozprawy m.in. referat programowy wygłoszony przezeń w Instytucie Gospodarki Światowej Uniwersytetu w Kolonii, w którym wywodził: „kto żyć chce, ten musi walczyć - i jeżeli walkę tę toczy cały naród, który chce żyć i musi żyć, to wówczas obszar, na którym naród żyć chce i musi, powinien być jego własnością i jest rzeczą całkowicie niemożliwą, by prócz tego narodu inny jeszcze naród na tym obszarze się pomieścił"s2. W swym sprawozdaniu z działalności za rok 1941 napisał: „od pierwszej manifestacji w początkowych dniach września 1939 r. (...) stale publicznie podkreślałem moje

${ }^{49}$ Ibidem, s. 92.

${ }^{50}$ Ibidem, s. 94-95.

${ }^{51}$ Główna Komisja Badania Zbrodni Niemieckich w Polsce, Proces Artura Greisera przed Najwyższym Trybunatem Narodowym, Warszawa 1946, s. 12.

${ }_{52}$ W. Kulesza, Wysiedlenia z Kraju Warty (Watrhegau) w świetle procesu Gauleitera Artura Greisera, [w:] Ludność cywilna w tódzkich obozach przesiedleńczych, red. J. Żelazko, Łódź 2010, s. 42 . 
stanowisko, że Niemiec jest panem tej ziemi, a Polak służącym”. „Ostdeutscher Beobachter" cytował wypowiedzi Gauleitera w czasie podróży inspekcyjnej po władanym przezeń Kraju Warty, instruujące jego urzędników: „panem i posiadaczem tej ziemi jest tylko Niemiec, a Polak po wsze czasy jest naszym parobkiem i sługą" 53 . Przestępstwo znieważenia narodu polskiego (art. 152 polskiego KK z 1932 r.), wprowadzone na wzór prawa włoskiego (art. 291 faszystowskiego KK), stało się zatem jednym z zarzutów w akcie oskarżenia przeciwko A. Greiserowi jako realizatorowi ideologii narodowosocjalistycznej w okupowanej Polsce. Przypominając o genezie ustawowego ujęcia czynu zabronionego znieważenia polskiego narodu podkreślić z naciskiem trzeba, że nie realizują jego znamion choćby dotykające poczucia godności indywidualnych odbiorców współczesne publikacje, których przykładem jest obszerne studium A. Leszczyńskiego pod wymownym tytułem „No dno po prostu jest Polska. Dlaczego Polacy tak bardzo nie lubią swojego kraju i innych Polaków"54.

\section{PRZESTEPSTWO ZNIEWAŻENIA NARODU POLSKIEGO I NAWOŁYWANIA DO NIENAWIŚCI W REALIACH WSPÓŁCZESNOŚCI}

Stanowisko polskich sądów w sprawie, w której zarzucono oskarżonym publiczne znieważenie narodu polskiego (art. $133 \mathrm{KK}$ ) oraz nawoływanie do nienawiści na tle narodowościowym (art. $256 \S 1 \mathrm{KK}^{55}$ ) zostało opisane w decyzji z 07.10.2014 r. Europejskiego Trybunału Praw Człowieka ${ }^{56}$. Stan faktyczny, do którego odniósł się krajowy wymiar sprawiedliwości, przedstawić można na podstawie uzasadnienia stanowiska sztrasburskiego Trybunału. Oskarżeni narodowości niemieckiej przyjechali do Polski 20.07.2004 r. i w nocy wywiesili na przystankach autobusowych i słupach ogłoszeniowych w mieście Bolesławiec, w pobliżu granicy z Niemcami, ponad trzydzieści plakatów formatu A3, na których widniał tekst $\mathrm{w}$ języku niemieckim i fotografie nieznanego pochodzenia, ukazujące masowe groby, zmasakrowane ciała i grupy ludzi w otwartych wagonach kolejowych. Na pierwszym z dwóch rodzajów tych plakatów napis głosił: „Polacy i Czesi - serdecznie witamy w UE!”, a pod nim stwierdzenie: „Nasz system spra-

${ }^{53}$ Główna Komisja Badania Zbrodni Niemieckich w Polsce, Proces Artura Greisera ..., s. 120.

${ }^{54}$ Warszawa 2017. Autor rekonstruuje „obraz, który Polak widzi w lustrze” zaznaczając, że „autostereotyp jest uogólnieniem wyobrażenia własnej wspólnoty, które bywa zakorzenione w rzeczywistości, ale jego relacja ze społecznymi faktami jest skomplikowana", s. 8.

${ }_{55}$ Art. $256 \S 1$. Kto publicznie propaguje faszystowski lub inny totalitarny ustrój państwa lub nawołuje do nienawiści na tle różnic narodowościowych, etnicznych, rasowych, wyznaniowych albo ze względu na bezwyznaniowość, podlega grzywnie, karze ograniczenia wolności albo pozbawienia wolności do lat 2.

56 Sprawa 10613/07, Hösl - Daum i inni v. Polska. 
wiedliwości pracuje pilnie, ponieważ morderstwo nie jest przedmiotem ustawowej limitacji. Dokumenty dotyczą polskich i czeskich okrucieństw dokonanych na Niemcach". Poniżej tego napisu zamieszczono fragmenty raportu „Z kraju śmierci”, który R. Jung, powołujący się na własne doświadczenia, opublikował w piśmie „Weltwoche”, opisując w nim zniszczone, opustoszałe niemieckie miasta z ulicami pełnymi zwłok i relacjonując okrucieństwa, jakich mieli dopuścić się Polacy na Niemcach w końcowej fazie wojny i po jej zakończeniu. Fragmenty teksu informowały m.in: ,jest prawdą, że na publicznym skwerze w mieście G. dziewczyny, kobiety i stare kobiety były gwałcone przez polskich milicjantów. Jest prawdą, że na stacji kolejowej w S. wszystkie transporty z uchodźcami były systematycznie ograbiane tak, że ludzie musieli dalej podróżować nago. Jest prawdą, że w sercu Śląska nie pozostało przy życiu ani jedno dziecko poniżej jednego roku życia, ponieważ wszystkie zmarły z głodu albo zostały zabite. Jest prawdą, że na Górnym Śląsku zakażone syfilisem kobiety, które wcześniej zostały zgwałcone dostawały jako »terapię« strzał w głowę. Jest prawdą, że nastąpiła fala samobójstw na tym terenie (...). Jest prawdą, że w tak zwanych obozach pracy więźniów umieszczano na noc po szyję w lodowatej wodzie, i że byli oni bici aż do utraty przytomności”. Dalej plakat informował: „po zakończeniu wojny 7 milionów Niemców zostało obrabowanych, wypędzonych, zgwałconych, atakowanych i zamordowanych. Więcej było Niemców, którzy zmarli w Polsce w 1225 obozach niż tych, którzy zmarli w transportach po ich wypędzeniu. W Lamsdorf, w obozie na Górnym Śląsku, z 8000 trzymanych tam ludzi zmarło 6048. W innych obozach na Górnym Śląsku panowało także nie dające się wypowiedzieć okrucieństwo. Powszechną praktyką w różnych obozach było zaplanowane od początku strzelanie do tych, którzy byli zbyt starzy, niezdolni do pracy lub chorzy. (...) Praca przymusowa i cierpienia w obozach nie mogą być skompensowane pieniędzmi, bez względu na sumę. To, co jest konieczne, to uświadomienie tych przestępstw w krajach, gdzie okrucieństwa te zostały dokonane. To, co jest także konieczne, to osądzenie pozostających przy życiu odpowiedzialnych za te zbrodnie. Zamiast tego totalna cisza otacza kwestię niemieckich ofiar".

Drugi rodzaj plakatów przedstawiał m.in. następujący tekst: „Dokumenty polskich i czeskich okrucieństw (...) Czy nasi przyjaciele w UE chcą uniknąć nowej oceny ich historii?? 15.000000 Niemców zostało obrabowanych, wywłaszczonych, setki tysięcy posłano do obozów koncentracyjnych i pracy przymusowej ... 3500000 Niemców zostało zabitych... Gdzie jest oskarżyciel, gdzie jest sędzia, ... są tylko Niemcy ... ludzie drugiej kategorii?? Około 11 milionów Niemców zmarło, w tym 7 milionów po zakończeniu wojny. Pokojowa Europa może istnieć tylko na fundamencie prawa i prawdy. Restytucja domów i gruntów wywłaszczonych wbrew prawu narodów powinna być dokonana teraz, w demokratycznej Polsce i Republice Czeskiej”. 
Postępowanie karne przeciwko sprawcom wywieszenia plakatów, w którym miały miejsce procesowe zwroty, zakończyło się w 2006 r. wyrokiem skazującym dwóch z nich, wydanym przez Sąd Okręgowy w Jeleniej Górze, utrzymanym następnie w mocy przez sąd Apelacyjny we Wrocławiu. Oskarżeni w sprawie uznani zostali za winnych znieważenia narodu polskiego (art. $133 \mathrm{KK}$ ), a także nawoływania do nienawiści na tle różnic narodowościowych (art. $256 \mathrm{KK}$ ). Za znieważające uznane zostały nieprawdziwe twierdzenia o rzekomych masowych zbrodniach popełnionych przez Polaków na niemieckiej ludności cywilnej w czasie II wojny światowej i po jej zakończeniu, ilustrowane fotografiami nieznanego pochodzenia. Jako nawołujące do nienawiści pomiędzy dwoma narodami uznane zostały żądania zwrotu ziemi i majątku pozostawionego przez niemiecką ludność na polskim terytorium. W uzasadnieniu skazania powołane zostały opinie opracowane przez profesorów prawa, historii i socjologii Uniwersytetu Wrocławskiego. W oparciu o te eksperckie opracowania skonstatował sąd orzekający w sprawie, że plakaty zawierały w swej treści wiele nieprawdy o Polakach, a podawane liczby o zmarłych Niemcach były rozmyślnie wymieniane w sposób chaotyczny, bez rozróżnienia, czy dotyczyły terytorium pod polską albo rosyjską administracją, czy Czechosłowacji. Podawane w takiej formie miały stworzyć podstawy do oskarżeń kierowanych głównie przeciwko Polakom. Liczby te zostały wzięte $\mathrm{z}$ antypolskich, wynikających z uprzedzeń, pamfletów politycznych. Tekst zamieszczony na plakatach, zawierający cytaty z artykułu R. Junga o sytuacji, jaka zapanowała na terytorium przekazanym pod polską administrację w następstwie porozumienia zawartego na Konferencji w Poczdamie, zawierał nieprawdę, gdyż celowo pomięto w nim informacje o rzeczywistych sprawcach m.in. zwykłych przestępstw kryminalnych. Informacja o Niemcach trzymanych w polskich obozach koncentracyjnych - stwierdził sąd - „,była także nieprawdziwa, gdyż obozy takie nie istniały, a fotografie umieszczone na plakatach nie mają dokumentalnej wartości, ponieważ nie jest możliwe ich zidentyfikowanie". Sąd podkreślił w uzasadnieniu swego orzeczenia, że eksperci jasno stwierdzili w wydanych opiniach, że treść plakatów jest nieprawdziwa i nie jest potwierdzona przez badania polskich i niemieckich historyków. W konkluzji uzasadnienia sąd wywiódł, że oskarżeni dopuścili się znieważenia narodu polskiego przez wystawienie w miejscach publicznych plakatów, których treść zawierała nieprawdę i imputowała Polakom rzekome zbrodnie, co nie zostało naukowo potwierdzone. Konkluzja ta opierała się na zeznaniach trzech świadków i na reakcji przechodniów, którzy widzieli plakaty.

W uzasadnieniu skazania za nawoływanie do nienawiści oceniono, iż oczywistym jest, że treść plakatów mogła wywołać uczucia wzburzenia, niechęci lub antagonizm pomiędzy narodami polskim i niemieckim. Podkreślone zostały rzekome polskie zbrodnie, włącznie z bezpodstawnym żądaniem zwrotu domów i ziemi 
pozostawionej przez Niemców na polskim terytorium, co może współcześnie odrodzić lub wzbudzić antagonizm części Niemców w stosunku do Polaków. Zgodnie z ekspercką opinią umieszczenie na plakacie fotografii ludzkich czaszek było nacelowane na wzbudzenie nienawiści. Uznając oskarżonych za winnych zarzucanych im czynów znieważenia narodu polskiego (art. $133 \mathrm{KK}$ ) i nawoływania do nienawiści (art. $256 \mathrm{KK}$ ) sąd skazał jednego z nich na karę dziesięciu miesięcy, a drugiego na osiem miesięcy pozbawienia wolności, zawieszając warunkowo w stosunku do obu wykonanie tej kary na okres trzech lat.

Obaj prawomocnie skazani przez polskie sądy zwrócili się do ETPC ze skargą, że pogwałcony został w stosunku do nich art. 10 Konwencji o ochronie praw człowieka i podstawowych wolności, gwarantujący każdemu wolność wyrażania opinii $^{57}$. Skarżący argumentowali, że art. 133 i $256 \mathrm{KK}$, przyjęte za podstawę ich skazania, zostały skonstruowane ściśle w celu dławienia historycznej debaty z powodów politycznych. Podnieśli, iż nie mogli zostać ukarani za rozgłaszanie faktów, nawet jeżeli fakty te szkodziły honorowi narodu. Nawet jeżeli cytowane na plakatach liczby nie były dokładne, pozostaje poza dyskusją, że Polacy popełnili straszne zbrodnie przeciwko niemieckim cywilom w czasie końcowego wypędzenia. Wydarzenia te są dobrze udokumentowane źródłowo i potwierdzone, jak istnienie obozów dla Niemców w powojennej Polsce. Skarżący przeprowadzili porównanie art. 133 polskiego KK z art. 301 tureckiego KK, który kryminalizuje znieważenie tureckiego narodu, państwa lub jego organów ${ }^{58}$.

${ }^{57}$ Art. 10. Wolność wyrażania opinii. Każdy ma prawo do wolności wyrażania opinii. Prawo to obejmuje wolność posiadania poglądów oraz otrzymywania i przekazywania informacji i idei bez ingerencji władz publicznych i bez względu na granice państwowe.

${ }^{58}$ Przepis ten został wprowadzony do tureckiego KK w 1936 r. jako art. 159; odnotować trzeba, że również na wzór art. 291 włoskiego KK z 1930 r., przewidując karę do trzech lat więzienia za publiczne znieważenie „turecczyzny”. Współcześnie podkreśla się, że przepisy przeniesione z „faszystowskiego kodeksu karnego Rocco" odpowiadały ówczesnemu pojmowaniu tureckiej państwowości, tj. istnieniu „tylko jednej partii, do której należało państwo, z jednym przywódcą". H. Hakeri, Reformbedarf im türkischen Strafrecht im 20. Jahrhundert und die neuen stafrechtlichen Gesetze am Beginn des 21 Jahrhunderts [w:] Materialen einer deutsch-japanischpolnisch - türkischen Tagung im Jahre 2015 in Rzeszów und Kraków (Polen), Hrsg. J. C. Joerden, A. J. Szwarc, Poznań 2016, s. 45. Według brzmienia obowiązującego od 2008 r. art. 301 (1) zagrożone jest karą od sześciu miesięcy do dwóch lat pozbawienia wolności publiczne znieważenie tureckiego narodu, państwa Republiki Tureckiej, wielkiego zgromadzenia narodowego lub państwowych organów wymiaru sprawiedliwości. W następnym ustępie zagrożone zostało taką samą karą znieważenie wojska lub sił bezpieczeństwa (art. 301 (2). W ust. 3 tego samego przepisu zastrzeżono, że wyrażanie przekonań w zamiarze przeprowadzenia krytyki nie stanowi czynu zabronionego. Ograniczenie ścigania polegające na tym, że postępowanie karne może być prowadzone tylko z upoważnienia ministra sprawiedliwości, ustanowione zostało w ust. 4 tego artykułu. Najgłośniejszym przypadkiem postępowania prowadzonego na podstawie art. 301 tureckiego KK, który zyskał złą sławę z powodu jego praktycznego stosowania, była sprawa O. Pamuka, laureata literackiej nagrody Nobla, któremu zarzucono, że znieważył turecczyznę przez publiczną 
Odnosząc się do skargi skazanych Trybunał przyjął za punkt wyjścia, że mechanizm ochrony praw człowieka ustanowiony w Konwencji jest posiłkowy w stosunku systemów krajowych, w których przewidziane środki muszą zostać wykorzystane przed wniesieniem sprawy na forum międzynarodowe. Kontrolna jurysdykcja, jaką sprawuje Trybunał, przed którym składana jest skarga przeciwko państwu, może zostać uruchomiona dopiero po tym, jak zostaną wyczerpująco wykorzystane środki przysługujące skarżącemu na poziomie krajowym. Takie stanowisko określone we wcześniejszym orzecznictwie sztrasburskiego Trybunału odniesione do skargi na Polskę w przedmiotowej sprawie wiodło do spostrzeżenia, że skarżący nie wyczerpali drogi krajowej, albowiem nie wnieśli stosownej skargi do polskiego Trybunału Konstytucyjnego z zarzutem, że art. 133 i 256 KK są sprzeczne z przepisem art. 54 Konstytucji, deklarującym każdemu wolność wyrażania swoich poglądów oraz pozyskiwania i rozpowszechniania informacji. Jako możliwy wskazał ETPC również zarzut sprzeczności wymienionych artykułów KK z art. $31 \S 3$ polskiej Konstytucji stanowiący, że wolność człowieka może zostać ograniczona tylko wtedy, gdy jest to konieczne w demokratycznym państwie (zasada proporcjonalności), a także z jej art. $42 \S 1$ wyrażającym zasadę nullum crimen, nulla poena sine lege poenali anteriori. Trybunał pouczył skarżących, że gdyby wnieśli skargę konstytucyjną, a TK orzekł o niezgodności z Konstytucją przepisów, na podstawie których zapadł w stosunku do nich wyrok skazujący, możliwym stałoby się zwrócenie do właściwego sądu o wznowienie postępowania karnego na korzyść oskarżonych, o czym stanowi art. 540 § 2 Kodeksu postępowania karnego. We wznowionym postępowaniu sądy powinny odrzucić te przepisy, które zostały uznane za sprzeczne z Konstytucją. W ten sposób rezultatem wznowionego postępowania mogłoby być stosownie zrekompensowane domniemane naruszenie art. 10 Konwencji. Wywód zamyka stwierdzenie, że w rozpatrywanej sprawie nie została wyczerpana droga postępowania krajowego, ponieważ zwracający się do Trybunału nie wnieśli wcześniej przewidzianej przez polskie prawo skargi konstytucyjnej ,przeciwko artykułom 133 i 256 Kodeksu Karnego”, co znaczy, iż nie wyczerpali drogi postępowania krajowego i dlatego ich skarga została odrzucona na mocy art. $35 \S 1$ i $§ 4$ Konwencji.

enuncjację odnoszącą się do ludobójstwa dokonanego w czasie I wojny światowej: „Turcy zabili na tej ziemi 30 tysięcy Kurdów i 1 milion Ormian”. Postępowanie prowadzone w 2005 r. zostało umorzone z powodu braku upoważnienia ministra sprawiedliwości do ścigania autora tej wypowiedzi. Podjęte ponownie, w sprawie tej samej wypowiedzi, zakończyło się w 2010 r. nałożeniem na jej autora obowiązku zapłacenia 6000 lir tureckich dla sześciu oskarżycieli, którzy jako Turcy poczuli się znieważeni stwierdzeniem Pamuka. 


\section{CZY ART. 133 KK JEST ZGODNY Z KONSTYTUCJĄ?}

Zreferowana powyżej decyzja o odrzuceniu skargi przez ETPC każe zastanowić się nad kwestią zgodności z konstytucją normy sankcjonującej zakaz publicznego znieważania narodu polskiego (art. $133 \mathrm{KK}$ ), co stałoby się przedmiotem wypowiedzi TK, gdyby skazani w wyżej zreferowanej sprawie wystąpili doń o stwierdzenie sprzeczności z konstytucją odnośnego przepisu. Punktem wyjścia uczynić należy wyrok TK z 21.09.2015 r., ${ }^{59}$ stwierdzający, że art. $49 \S 1 \mathrm{KW}$ (statuujący odpowiedzialność za wykroczenie polegające na demonstracyjnym okazywaniu w miejscu publicznym lekceważenia Narodowi Polskiemu, Rzeczypospolitej Polskiej lub jej konstytucyjnym organom) jest zgodny z art. 54 ust. 1 Konstytucji (zapewniającym każdemu wolność wyrażania swoich poglądów oraz pozyskiwania i rozpowszechniania informacji), a także z art. 31 ust. 3 Konstytucji (jako dopuszczającym ograniczenie konieczne w demokratycznym państwie), a także pozostaje $\mathrm{w}$ zgodzie $\mathrm{z}$ art. 10 Konwencji o ochronie praw człowieka i podstawowych wolności. Trybunał zaznaczył w uzasadnieniu swego stanowiska, że ustrojodawca traktuje naród polski jako wspólnotę nie tyle etniczną w znaczeniu „wspólnoty krwi”, gdyż byłoby to bezprzedmiotowe wobec migracji i mieszania się różnych narodowości w wielonarodowej I i II Rzeczypospolitej, jak i w wyniku wojen i przemarszu obcych armii, ile kulturową. Preambuła do Konstytucji stwierdza jednoznacznie, że Naród Polski to „wszyscy obywatele Rzeczypospolitej”, z czego wynika, że nie mają znaczenia takie czynniki, jak narodowość, rasa czy wyznanie, a istotą przynależności doń jest „poczucie państwowe uzewnętrznione przez posiadanie polskiego obywatelstwa".

Choć art. $133 \mathrm{KK}$ nie był objęty skargą konstytucyjną, to można jednak z wywodu TK wysnuć wniosek, że rozróżnienie przestępstwa znieważenia polskiego narodu od wykroczenia polegającego na demonstracyjnym okazywaniu mu lekceważenia jest reakcją prawnokarną w sposób należyty zróżnicowaną, „co silnie przemawia za uznaniem całej regulacji za proporcjonalną sensu stricto". Ustawodawca - podkreślił TK - prawidłowo wyważył karygodność zachowań realizujących znamiona przestępstwa $\mathrm{w}$ stosunku do stanowiących wykroczenie „właściwie różnicując stopień represji za każde z nich”. Jest tak dlatego, że „ustawodawca spenalizował w k.k. czyny poważniejsze, o większej wadze, natomiast czyny o mniejszym ciężarze gatunkowym objął sankcją wykroczeniową". Rozumując a minori ad maius można przeto wnioskować, że uznanie karalności za wykroczenie lekceważenia narodu polskiego za niesprzeczne z konstytucyjną deklaracją wolności wyrażania poglądów wskazuje, iż nie pozostaje w kolizji z nią kryminalizacja znieważenia jako głębiej wyrażającego pogardę dla chronionego

${ }^{59}$ K 28/13,OTK-A 2015, nr 8, poz. 120. 
podmiotu. Odnośnie do karalności publicznego lekceważenia zostało podkreślone, że „celem ustawodawcy jest ochrona suwerena (Narodu Polskiego), dobra wspólnego (Rzeczypospolitej Polskiej) oraz konstytucyjnych organów państwa przed różnorakimi atakami o mniejszym nasileniu niż znieważenie". Następnie zaznaczono, że ,penalizacja tego rodzaju działań niewątpliwie służy autorytetowi suwerena (Narodu Polskiego), samej Rzeczypospolitej oraz jej organów, ponieważ drogą prewencji ogólnej (indywidualnej również) zapobiega podważaniu ich autorytetu w miejscach publicznych, a przez to pozwala na zachowanie ładu i porządku publicznego i zapewnia życiu społecznemu harmonię, sprzyjając integracji społecznej wokół najważniejszych wartości”. Kryminalizacja zachowań polegających na publicznym znieważeniu, dającym upust pogardzie, czy zelżeniu, a także łagodniejszej formy, jaką jest demonstracyjne okazywanie lekceważenia, nie godzi w swobodę debaty publicznej ani nie ogranicza wolności słowa, gdyż działania takie nie wnoszą jakiegokolwiek wkładu do takiej debaty. Wypowiedzi o inkryminowanym charakterze nie polegają na stawianiu racjonalnych zarzutów ani nie służą ,zdaniem Trybunału Konstytucyjnego, zaprezentowaniu jakiegokolwiek osądu, możliwego do weryfikacji w kategoriach prawdy i fałszu, i pozwalającego na wyciągnięcie konstruktywnych wniosków”. Dodano, iż „ani Naród Polski, ani Rzeczpospolita Polska nie podejmują - same w sobie - konkretnych działań w sferze publicznej, które mogłyby stać się tematami publicznej debaty”. W podsumowaniu referowanej części wywodu napisano, że art. 49 § $1 \mathrm{KW}$, jakkolwiek ogranicza wolność słowa czy też swobodę wypowiedzi, to jednak nie thumi debaty publicznej, a jedynie eliminuje z niej wypowiedzi i zachowania będące „niewątpliwym w swej intencji uzewnętrznieniem negatywnych uczuć, żywionych wobec wartości konstytucyjnych najwyższej rangi”. Gdyby ustawodawca rozważał eliminację tego przepisu z systemu prawa karnego, to „powinien on jednak pamiętać o historycznym doświadczeniu Polski i Polaków w ostatnich dwóch wiekach, przemawiającym za oczekiwaniem poszanowania wolnego i suwerennego państwa i jego organów przez osoby znajdujące się pod władzą Rzeczypospolitej”, które to wskazanie odnieść można także do ewentualnego zakwestionowania racji prawnokarnego zakazu publicznego znieważania narodu i państwa polskiego, sankcjonowanego w art. $133 \mathrm{KK}$.

Clou wywodu TK dokonującego wykładni pojęć lekceważenia znieważenia narodu polskiego zawarte jest w tezie głoszącej, że obejmują one twierdzenia „nieweryfikowalne w kategoriach prawdy i fałszu” i jako takie nie wzbogacające debaty publicznej. Teza ta jest zgodna z komentarzem J. Makarewicza do art. 152 KK z 1932 r., wymaga jednak rozważenia na gruncie przytoczonych wyżej twierdzeń, zawartych w uzasadnieniu wyroków skazujących sprawców, którzy rozwiesili plakaty informujące o Niemcach trzymanych pod koniec wojny i po jej zakończeniu w 1225 polskich obozach. Sądy obu instancji stwierdzi- 
ły, w oparciu o opinie biegłych, że informacja o polskich obozach koncentracyjnych była nieprawdziwa, gdyż obozy takie nie istniały, i nie jest potwierdzona przez badania polskich i niemieckich historyków. O zakwalifikowaniu treści plakatów jako znieważających naród polski zdecydowała jednak jej falsyfikacja, będąca rezultatem badania napisów przez ekspertów właśnie w kategoriach prawdy i fałszu. Znaczy to, że sądy orzekające w sprawie uznały, iż znieważenie narodu jako czyn karalny na podstawie art. 133 KK może polegać także na podaniu nieprawdziwej, hańbiącej informacji o faktach historycznych. Wydaje się więc, że sądy uznały, iż informacja o „polskich obozach koncentracyjnych”, wskazująca ich liczbę, oraz twierdzenie, że zginęły w nim setki tysięcy Niemców, tak dalece odbiegała od prawdy, że będąc z gruntu fałszywą, stanowiła znieważenie polskiego narodu i z takim zamiarem oskarżeni umieścili w miejscach publicznych zawierające ją plakaty. O przyjętej przez sądy kwalifikacji prawnokarnej zdecydował także kontekst, w jakim napisano o polskich obozach, z którego wynikało przypisanie Polakom popełnienia zbrodni na milionach Niemców oraz obowiązku zwrócenia gruntów i domostw pozostałych po przesiedlonych. Nadmienić trzeba, że współcześnie twierdzenia o rzekomych polskich zbrodniach zamieszczane są - jak podaje D. Schenk - na internetowych forach dyskusyjnych dla prawicowych ekstremistów, a także w publikacjach o takim charakterze: „w latach 1945-1947 r. na wschód od Odry i Nysy znajdowało się w sumie 1225 polskich obozów koncentracyjnych (polnische Konzentrationslager) i 227 więzień, w których stosowano tortury i gdzie odbywały się bestialskie polskie orgie mordowania (bestialische polnische Mordorgien)”. Twierdzi się, że „od 1945 r. zmarło w polskich KZ 6-8 milionów Niemców”, a „15 milionów Niemców zostało wypędzonych z niemieckich terenów wschodnich, z których następnie zmarło ponad 2 miliony". Zarzuca się Polsce, że to ona była agresorem i wypowiedziała w 1939 r. wojnę Niemcom ${ }^{60}$. Przyjąć przeto trzeba, że nasilenie oczywistej nieprawdy sprawia, iż zawierające ją wypowiedzi, ze względu na stężenie cechującego je immanentnego fałszu, stają się nieweryfikowalne i jako takie stanowią znieważenie prawem chronionego podmiotu, ze swej natury nie dające się analizować w kategoriach prawdy i fałszu. Innymi słowy rzecz ujmując - ilość historycznej nieprawdy przechodzi w jakość, którą ocenić należy w ramach prawnokarnej kategorii znieważenia polskiego narodu.

${ }^{60}$ D. Schenk, Wadliwe kody pamięci-złe nawyki, umyślne kłamstwa, niedbalstwo? Perspektywa prawa niemieckiego a rewizjonizm historyczny, [w:] Wadliwe kody pamięci, red. A. Nowak-Far, Ł. Zamęcki, Warszawa 2015, s. 21. Zob. także P. Madajczyk, Przyłączenie Śląska opolskiego do Polski 1945-1948, Warszawa 1996, s. 237. 
Zaznaczyć równocześnie trzeba, że informacja prawdziwa o miejscu i czasie funkcjonowania danego obozu oraz liczbie zmarłych w nim Niemców w żadnym przypadku nie może być uznaną za realizującą znamiona czynu zabronionego opisanego w art. $133 \mathrm{KK}^{61}$. Nie mogą przeto spotkać się z prawnymi przeszkodami

${ }^{61}$ Jak podano w opracowaniu Niemcy w Polsce 1945-1950. Wybór dokumentów, t. 1, red. A. Borodziej, H. Lemberg, Warszawa 2000, s. 82, „wiosną 1945 r. według dokumentów MBP istniało co najmniej 88 więzień, 14 obozów pracy i 2 zakłady poprawczo-wychowawcze", w których przetrzymywano osoby uznane za Niemców. Zaznacza się, że uwięzieni Niemcy w podobnym stopniu byli ofiarami tortur, głodu i chorób, jak Polacy uznani za wrogów „władzy ludowej” - „terror stabilizujący nową władzę był stosowany uniwersalnie, jako sposób postępowania wobec wszystkich grup społecznych uznanych za wrogie”, tamże s. 84. Ocenia się, że: „,warunki bytowe w obozach pracy były koszmarne, porównywalne do tych panujących w sowieckich łagrach czy niemieckich kacetach. Przeludnienie, głód i choroby były oprócz niewolniczej pracy głównymi przyczynami dużej śmiertelności więźniów (budynek, zwany trupiarnią, wyraźnie zaznaczono na każdym z planów obozów)”. B. Kopka, Niemcy $i$ Polacy w obozach pracy administrowanych przez resort bezpieczeństwa publicznego $w$ Polsce 1945-1954: terror i praca, [w:] Wtadze komunistyczne wobec ludności niemieckiej w Polsce w latach 1945-1989, red. A. Dziurok, P. Madajczyk, S. Rosenbaum, Warszawa 2016, s. 478.

Według ustaleń śledztwa prowadzonego w 2001 r. przez Oddziałową Komisję Ścigania Zbrodni przeciwko Narodowi Polskiemu w Katowicach (sygn. akt S/01/Zk), w Centralnym Obozie Pracy w Jaworznie, którego podobozy utworzono praktycznie przy wszystkich kopalniach i dużych zakładach przemysłowych, z zatrzymanych tam Ślązaków, niemieckich cywili oraz jeńców, w latach 1945-1947 zmarło 7000 osób, z powodu głodu, ciężkiej, wyniszczającej pracy i złych warunków sanitarnych, powodujących szerzenie się chorób epidemicznych (tyfusu i czerwonki), a także w następstwie znęcania się nad więźniami przez funkcjonariuszy tego obozu.

W śledztwie prowadzonym przez tą samą Oddziałową Komisję przeciwko S. Morelowi, komendantowi Obozu Pracy w Świętochłowicach-Zgodzie (sygn. akt 61/01/Zk) ustalono, że w 1945 r. do obozu tego kierowano ludność niemiecką, a także Górnoślązaków (wśród nich także powstańców śląskich, członków AK, Polaków z centralnej Polski oraz obywateli 8 innych państw). Z zidentyfikowanych z nazwiska 2999 osób zmarło 1695. Skierowany do państwa Izrael polski wniosek o ekstradycję S. Morela spotkał się z odmową $(1999,2005)$ uzasadnioną przedawnieniem się według prawa izraelskiego - czynów zarzucanych podejrzanemu. W. Kulesza, Europejski nakaz aresztowania jako instrument stosowania prawa karnego w Unii Europejskiej, [w:] Studia Prawno-Europejskie, t. IX, red. M. Seweryński, Łódź 2007, s. 106.

W obozie w Mysłowicach zmarło 2200 osób, co nie zostało jednak podane w zachowanej dokumentacji archiwalnej. W dokumentach MBP odnotowano w latach 1945-1947 łącznie w Polsce tylko 6140 zgonów, które to ,zestawienie było w oczywisty sposób niewiarygodne”. Niemcy w Polsce 1945-1950..., s. 91-92.

Niepełne pozostają także zestawienia sporządzone w 1993 r. na podstawie ocalałych akt więziennych i części obozów, w których nie rozróżniano narodowości więźniów - liczba zgonów w Jaworznie miała wynosić 6987, dla innych obozów 3932. Niemcy w Polsce 1945-1950 ..., s. 92. Rzeczywista liczba zmarłych w obozach Niemców nie została ustalona.

Zaznaczyć trzeba, że obozy, w których większość ofiar stanowili Niemcy, nie zostały utworzone przez ówczesne polskie władze w ramach ideologicznie uzasadnianego planu systemowego wyniszczenia osób tej narodowości, które znalazły się na polskim terytorium. Popełniane na nich w sposób celowy zbrodnie wynikały z działania na własną rękę sadystycznych komendantów i funkcjonariuszy, czemu władze starały się, choć mało skutecznie, zapobiegać (bestialski komendant S. Morel ukarany został kilkudniowym aresztem domowym). Cz. Gęborski, komendant obozu 
publikacje dokumentalne, których przykładem jest zawierająca relacje naocznych świadków książka M. Łuszczyny pod znamiennym tytułem „Mała zbrodnia. Polskie obozy koncentracyjne" (Kraków 2017).

\section{OKREŚLENIE „POLSKIE OBOZY KONCENTRACY JNE” W ODNIESIENIU DO OBOZÓW UTWORZONYCH PRZEZ III RZESZE W OKUPOWANEJ POLSCE}

Uznanie przez sądy za znieważenie narodu polskiego w rozumieniu art. 133 KK twierdzenia o „1225 polskich obozach koncentracyjnych”, w których miano dokonywać masowych zbrodni na Niemcach rodzi pytanie, czy taką samą kwalifikacją prawnokarną mogą zostać objęte określenia „polskie obozy koncentracyjne” w odniesieniu do zorganizowanych przez III Rzeszę obozów na polskim terytorium. Skoro nieprawdziwe historycznie twierdzenie realizuje znamiona znieważenia narodu polskiego, to tym bardziej obraża narodową godność nazwanie ,polskimi” niemieckich obozów koncentracyjnych i zagłady. Określenia w rodzaju „polski obóz zagłady Auschwitz”, „,polski obóz koncentracyjny Majdanek”, mogą nieznającym historii co najmniej sugerować, że Polacy są współwinni zbrodni popełnionych w tak nazywanych miejscach, a powtarzane - fałszują kody pamięci europejskich społeczeństw. Polskie protesty wobec zagranicznych mediów, w których pojawiają się takie sformułowania skutkują z reguły sprostowaniem i wyjaśnieniem, że nie było zamiarem ani autora, ani wydawcy publikacji fałszowanie historii i obrażanie polskiego społeczeństwa, lecz jedynie wskazanie geograficznego położenia obozów utworzonych przez III Rzeszę. Pomimo takich usprawiedliwień ma miejsce swego rodzaju „recydywa” używania tych syntagm, o czym świadczy częstotliwość reak-

w Łambinowicach, były więzień obozu hitlerowskiego, twierdził, że rozliczał się z Niemcami za lata poprzednie, aresztowany został na kilka miesięcy po masowym zamordowaniu ponad czterdziestu więźniów podczas rzekomej ucieczki, w czasie pożaru baraków. E. Nowak, Cień Łambinowic, Próba rekonstrukcji dziejów obozu pracy w Eambinowicach 1945-1946, Opole 1991, s. 156.

W zachowanych dokumentach znajduje się m.in. informacja o skazaniu przez Wojskowy Sąd Rejonowy w Katowicach 06.07.1946 r. na karę śmierci dwóch milicjantów z posterunku MO w Ługnianach za wyrafinowane okrucieństwo prowadzące do śmierci aresztowanych Niemców, o których informowali władze zwierzchnie, że ,zbiegli z aresztu”, a także za zwykłe rabunki. Stwierdzono także, że skatowani, zwolnieni z aresztu umierali wkrótce po tym wskutek uszkodzenia organów wewnętrznych. W sprawie tej odnotowano, że „oskarżeni tłumaczyli się tym, iż ofiary ich były narodowości niemieckiej, oni sami zaś tak wielkich cierpień doznali od niemców (pisane z małej litery - W.K.) w czasie okupacji, iż obecnie nie mogli powstrzymać swego uczucia zemsty". W rozkazie nr 88 ministra bezpieczeństwa publicznego napisano o tej sprawie: „Sąd w uzasadnieniu wyroku podkreślił, iż prawodawstwo polskie nie uzależnia wymiaru sprawiedliwości od narodowości osób poszkodowanych i choćby niemcy stosowali względem narodów podbitych wyrafinowane metody gestapowskie, co zostało potępione przez cały świat cywilizowany, to Polakom nie wolno w żadnym wypadku stosować tych metod, nawet wobec niemców.” Niemcy w Polsce 1945-1950..., s. 245-246. 
cji ze strony polskiej dyplomacji ${ }^{2}$. Powtarzalność określenia „polskie obozy koncentracyjne" sprawia, że trudno przyjąć z dobrą wiarą thumaczenie, iż miał miejsce „lapsus linguae" ze strony autora prasowego doniesienia, nie dostrzeżony następnie w toku redakcyjnego opracowania jego tekstu przed wydrukowaniem na łamach gazety. Trudno oprzeć się wrażeniu, że przynajmniej część publikacji zawierających takie sformułowania stanowi, nie wyłączone spod kontrolnej funkcji świadomości osób odpowiedzialnych, swego rodzaju zaczepki, testujące polską uwagę, wrażliwość na nie i determinację w występowaniu ze sprzeciwem wobec nich. Wbrew twierdzeniu ex post o zwykłej pomyłce spowodowanej gorączką pracy redakcyjnej poprzedzającą publikację, wydaje się, iż kierując tekst do druku ex ante przyjmuje się, iż reakcją na przewidywany jako możliwy polski protest będzie ewentualne „,przeproszenie za przejęzyczenie”, kończące całą sprawę. Dodaje się także, że chodziło tylko o wskazanie, że wymieniony z nazwy obóz koncentracyjny, nazwany polskim, znajdował się poza granicami Niemiec. Z krytycznego oglądu samego tekstu zwykle nie wynika zamiar znieważenia polskiego społeczeństwa, przez autora i redaktora prasowej publikacji, choć zauważyć trzeba, że nie jest praktykowane nazywanie obozu Mauthausen ,austriackim” pomimo, iż znajdował się on poza granicami „starej Rzeszy”. Zwrócić trzeba uwagę i na to, że przestępstwo to jest przestępstwem umyślnym, do którego komentarz zastrzega, że może być popełnione tylko ze szczególnego rodzaju zamiarem, wyrażającym wolę znieważenia - cum animo iniuriandi ${ }^{63}$. Cudzoziemski autor tekstu, jak również redaktor wydania, poinformowani, że publikacja narusza dobro prawne chronione przez art. $133 \mathrm{KK}$ mogą powoływać się także na swą nieświadomość istnienia w polskim prawie zakazu znieważania narodu polskiego, zwłaszcza, że współczesne ustawodawstwa krajów europejskich nie przewidują podobnych zakazów w stosunku do innych narodów.

\section{OKREŚLENIE „POLSKIE OBOZY KONCENTRACYJNE” A KARALNE ZAPRZECZANIE ZBRODNIOM NAZISTOWSKIM}

Na publiczną wypowiedź zawierającą sformułowanie ,polskie obozy koncentracyjne” spojrzeć można także przez pryzmat zespołu znamion czynu zabronione-

62 E. Stasiak-Jazukiewicz, Medialny kontekst ,wadliwego kodu pamięci”. Studium przypadków użycia przez prasę niemiecka nieprawdziwych określeń nazistowskich obozów zagłady i obozów koncentracyjnych, założonych przez Niemców w okupowanej Polsce, [w:] Wadliwe kody pamię$c i$, red. A. Nowak-Far, Ł. Zamęcki, Warszawa 2015, s. 37. Ibidem: A. Nowak-Far, Wadliwe kody pamięci o zbrodniach ludobójstwa. Podstawowe problemy oceny aksjologicznej i prawnej, s. 89; N. Sienkiewicz-Bożyk, M. Sykulska-Przybysz, Możliwość postępowań o używanie wadliwych kodów pamięci w Niemczech, s. 171.

${ }^{63}$ P. Kardas, [w:] Kodeks karny, t. II, red. A. Zoll, s. 141; J. Kulesza, [w:] Kodeks karny, Cześć szczególna, t. I, red. M. Królikowski, R. Zawłocki, Warszawa 2013, s. 103. 
go „kłamstwa o Auschwitz”, opisanego w art. 55 ustawy z 18.12.1998 r. o Instytucie Pamięci Narodowej - Komisji Ścigania Zbrodni przeciwko Narodowi Polskiemu. Przepis ten stanowi, że podlega karze ten, „kto publicznie i wbrew faktom zaprzecza zbrodniom, o których mowa w art. 1 pkt.1...", tj. zbrodniom nazistowskim, zbrodniom komunistycznym, a także zbrodniom przeciwko pokojowi, ludzkości lub zbrodniom wojennym, popełnionym od dnia 1 września $1939 \mathrm{r}$. Wprawdzie przepis ten miał na celu przede wszystkim kryminalizację publicznych wypowiedzi negujących zbrodnię ludobójstwa dokonanego w Auschwitz-Birkenau i innych miejscach zagłady, to jednak wynikający z niego zakaz odnosi się także do wypowiedzi zaprzeczających niemieckiemu sprawstwu zbrodni tam popełnionych. Zaprzeczeniem takim jest w analizowanym kontekście użycie określenia „polski”, stanowi ono bowiem implicite zanegowanie, wbrew faktom, że wszystkie te obozy zostały zorganizowane przez niemieckiego okupanta, który dokonał w nich zbrodni przeciwko ludzkości w najcięższej postaci - ludobójstwa. Posłużenie się zatem budzącym zasadniczy sprzeciw określeniem implikuje zaprzeczanie niemieckich zbrodni i równocześnie przypisuje je Polakom. Zaznaczyć trzeba, że dobro prawem chronione przed wypowiedziami realizującymi znamiona „kłamstwa o Auschwitz” to nie tylko pamięć kolektywna polskiego społeczeństwa. To dobro prawem chronione ma charakter ponadnarodowy i transgraniczny, ponieważ chronione jest współcześnie w krajach europejskich, w których wypowiedzi zawierające kłamstwo o Auschwitz uruchamiają reakcję prawną. Dobrem chronionym, w które godzą inkryminowane sformułowania, jest pamięć zbiorowa współczesnych, stanowiąca element szerszego pojęcia, jakim jest ludzka godność tych wszystkich, którzy crimine temporis z racji przynależności narodowej lub rasowej zaliczeni zostaliby, według kryteriów ideologii narodowo socjalistycznej, do kategorii ,podludzi”"

Bezprawność określenia „polskie obozy koncentracyjne” wynika z ustanowienia prawnokarnej ochrony pamięci zbiorowej, która jest dobrem prawnym w rozumieniu polskiego prawa karnego, a także w systemach prawnych państw uznających za czyny zabronione publiczne wypowiedzi stanowiące „Auschwitzlüge" ${ }^{\text {. }}$.

Niezależnie zatem od miejsca zdarzenia, użycie w wypowiedzi określenia „polski” w odniesieniu do niemieckiego obozu koncentracyjnego traktować trzeba jako czyn bezprawny, powodujący uszczerbek w dobru o znaczeniu uniwersalnym. Powszechna dostępność wiedzy o ludobójstwie - jego ofiarach, miejscach jego dokonania i sprawcach sprawia, że wiedza ta jest wyznacznikiem poziomu cywilizacyjnego współczesnych społeczeństw. Posłużenie się inkrymi-

${ }^{64}$ W. Kulesza, „Kłamstwo o Auschwitz” jako czyn zabroniony w polskim i niemieckim prawie karnym, [w:] Aktualne problemy prawa karnego. Księga pamiatkowa z okazji Jubileuszu 70. urodzin Profesora Andrzeja J. Szwarca, red. Ł. Pohl, Poznań 2009, s. 307.

${ }_{65}$ M. Matuschek, Erinnerungsstrafrecht. Eine Neubegründung des Verbots der Holocaustlungnung aus rechtsvergleichender und sozialphilosophischer Grundlage, Berlin 2012, s. 11 i n. 
nowanym sformułowaniem o „polskim obozie koncentracyjnym” jest w każdym wypadku zachowaniem bezprawnym w świetle normy prawnej chroniącej pamięć kolektywną, przy czym warunkiem odpowiedzialności karnej sprawcy jest ustalenie, że działał on z zamiarem, tj. ze świadomością i wolą zaprzeczania niemieckim zbrodniom. Brak takiego zamiaru, przy równoczesnym naruszeniu z lekkomyślności lub niedbalstwa reguł ostrożności w obchodzeniu się $\mathrm{w}$ formułowaniu publicznych enuncjacji z pamięcią zbiorową, ukształtowaną na gruncie powszechnie znanych faktów historycznych, nie jest w świetle prawa karnego wystarczającą przesłanką dla stwierdzenia, że sprawca popełnił umyślnie czyn zabroniony. Umyślność sprawcy, z jaką zaprzecza on faktom zbrodni jest bowiem warunkiem jego odpowiedzialności karnej - elementem konstytutywnym przestępstwa „kłamstwa o Auschwitz”. Brak umyślności w realizacji znamion przestępstwa, mimo że wyłącza odpowiedzialność karną sprawcy, to jednak nie odbiera naruszonej normie prawnokarnej funkcji potępiającej sprawcę nieumyślnie atakującego dobro chronione prawem. Inaczej rzecz ujmując w tych przypadkach, w których mówiący o polskich obozach koncentracyjnych nie działa cum animo negationis (z zamiarem negowania) faktów zbrodni nazistowskich odpada jego odpowiedzialność karna, lecz nie zostaje uchylona bezprawność wypowiedzi ${ }^{66}$.

\section{PUBLICZNE UŻYCIE OKREŚLENIA} „POLSKIE OBOZY KONCENTRACYJNE” JAKO PRZESTĘPSTWO SUI GENERIS?

Powtarzające się w zagranicznych mediach określenia „polskie” obozy koncentracyjne, śmierci, zagłady, wskazywane są w uzasadnieniach wprowadzenia do polskiego prawa karnego odrębnego przestępstwa polegającego na publicznym używaniu takich określeń. Kryminalizacją miałyby zostać objęte zachowania każdego, „kto publicznie pomawia Naród Polski o udział, organizowanie lub odpowiedzialność za zbrodnie komunistyczne lub nazistowskie". Taki opis czynu znalazł się w dodanym w 2006 r. do KK przepisie art. 132a, który stracił moc w 2008 r. na skutek ustalenia przez TK, że przy jego uchwaleniu nie dochowano właściwego trybu legislacyjnego ${ }^{67}$. Według projektu z 2013 r. stosowny przepis, wymieniający szczegółowo inkryminowane określenia, miałby się znaleźć w znowelizowanej ustawie o IPN, jako jej art. $55 \mathrm{a}^{68} \mathrm{~W}$ projekcie z 2016 r. nie zosta-

${ }^{66}$ W. Kulesza, Wadliwe kody pamięci a zbiorowa pamięć jako dobro społeczne chronione prawem karnym, [w:] Wadliwe kody pamięci, red. A. Nowak-Far, Ł. Zamęcki, Warszawa 2015, s. 162.

${ }^{67}$ Wyrok TK z 19.09.2008 r. K 5/07, OTK-A 2008, nr 7, poz 124.

${ }^{68}$ Projekt z 15.10.2013 r. przewidywał umieszczenie w ustawie o IPN art. 55a: Kto publicznie używa słów „,polskie obozy śmierci”, „polskie obozy zagłady”, „polskie obozy koncentracyjne” 
ły wymienione takie określenia, jednakże normą sankcjonującą miałoby zostać objęte ich publiczne używanie, także w przypadkach nieumyślnego zachowania tego, kto przypisywałby „Narodowi Polskiemu udział, organizowanie, odpowiedzialność lub współodpowiedzialność za popełnienie zbrodni przez III Rzeszę Niemiecką..." ${ }^{\circ 9}$. Autor, także cudzoziemiec, wypowiedzi realizującej, choćby nieumyślnie, zespół znamion tak opisanego czynu zabronionego miałby ponosić odpowiedzialność karną przed polskim sądem, bez względu na to, czy jego zachowanie stanowiło czyn zabroniony w rozumieniu przepisów obowiązujących w państwie, w którym został on popełniony ${ }^{70}$.

Rozważenie, czy racjonalną jest kryminalizacja publicznych wypowiedzi zawierających określenia „polski” obóz na oznaczenie niemieckiego obozu jako miejsca dokonanych tam zbrodni przeciwko ludzkości, poprzedzić trzeba hipotezą, według której - zdaniem projektodawców - wypowiedzi tego rodzaju nie realizują zespołu znamion czynów zabronionych znieważenia narodu polskiego (art. $133 \mathrm{KK}$ ) ani kłamstwa o Auschwitz (art. 55 ustawy o IPN). Wydaje się bowiem, że taką właśnie hipotezę wykładni przyjmują autorzy projektów przepisu, który wyraźnie wymieniałby inkryminowane słowa (projekt z 2013 r.) lub zakazywał przypisywania narodowi polskiemu narodowosocjalistycznych zbrodni, mających miejsce także poza obozami koncentracyjnymi, śmierci i zagłady (projekt z 2016 r.). W uzasadnieniach obu projektów napisano, że wobec powtarzania się $\mathrm{w}$ dyskursie publicznym wypowiedzi godzących bezpośrednio $\mathrm{w}$ dobre imię obywateli polskich i działających destrukcyjnie na wizerunek RP, zwłaszcza za granicą, konieczne jest stworzenie skutecznych narzędzi prawnych, pozwalających prowadzić wytrwałą i konsekwentną politykę historyczną władz polskich w zakresie przeciwdziałania fałszowaniu polskiej historii i ochrony dobrego imienia polskich obywateli. Opis czynności sprawczej jako „przypisywanie” zbrodni nazistowskich lub odpowiedzialności za nie, obejmować ma m.in. używanie określeń „polskie obozy” pozwalając na uniknięcie kazuistyki - zdaniem pro-

lub innych, które stosują przymiotnik „polskie” wobec niemieckich nazistowskich obozów koncentracyjnych i ośrodków zagłady, podlega grzywnie, ograniczeniu wolności lub karze pozbawienia wolności do lat 5 .

${ }^{69} \mathrm{~W}$ projekcie z 17.02.2016 r. nadano art. 55a ustawy o IPN brzmienie: 1 . Kto publicznie i wbrew faktom przypisuje Narodowi Polskiemu udział, organizowanie, odpowiedzialność lub współodpowiedzialność za popełnienie zbrodni przez III Rzeszę Niemiecką, o których mowa w art. 1 pkt 1 podlega karze pozbawienia wolności do lat 5 . Wyrok podawany jest do publicznej wiadomości. 2. Jeżeli sprawca działa nieumyślnie, podlega karze grzywny lub karze ograniczenia wolności.

${ }^{70}$ Projekt przewiduje zamieszczenie w ustawie o IPN przepisu art. 55b stanowiącego, że „niezależnie od przepisów obowiązujących w miejscu popełnienia czynu zabronionego, niniejszą ustawę stosuje się do obywatela polskiego oraz cudzoziemca w razie popełnienia przestępstw, o których mowa w art. 55 i art. 55a". 
jektodawców - bezzasadnie zawężającej możliwość inkryminowania tego typu zachowań. Wydaje się jednak, iż zachowania zarówno dokładniej, jak i bardziej ogólnie wskazane jako czynności sprawcze w zgłaszanych projektach, są już skryminalizowane w obowiązującym stanie prawnym. Nie chodzi przeto o brak kryminalizacji tego rodzaju czynów, lecz o to, że na podstawie obowiązujących przepisów sankcjonujących naruszenia nie zapadły, jak dotąd, wyroki skazujące sprawców, którzy dopuścili się ich popełnienia zagranicą. De lege lata stwierdzić trzeba, że w polu kryminalizacji znajdują się zachowania, o których projektodawcy sądzą, że dopiero spełnienie ich postulatów de lege ferenda sprawi, że staną się czynami karalnymi. Przypuszczać można, że projektodawcom chodzi o nadanie przepisom takiej formy stylistycznej, która nie wymagając wykładni, uświadamiać będzie wszystkim potencjalnym sprawcom, że wypowiedzenie lub napisanie słów o ,polskich obozach” jest przestępstwem według prawa polskiego, także w przypadkach, gdy sprawcy nie towarzyszy zamiar popełnienia czynu zabronionego, lecz można przypisać mu swego rodzaju językowe niedbalstwo. Wątpliwe wydaje się, aby cudzoziemiec, powołujący się na brak zamiaru popełnienia czynu zabronionego, został wydany Polsce przez państwo, w którym miała miejsce jego wypowiedź, jako oskarżony przez prokuraturę o nieumyślne przypisanie narodowi polskiemu nazistowskich zbrodni. Przedstawiony we wcześniejszym fragmencie rozważań przypadek osądzenia przez polski sąd sprawców, którzy w miejscach publicznych umieścili plakaty o polskich obozach i ich niemieckich ofiarach, wymaga w tym miejscu podania, że zostali oni ujęci w Polsce, w czasie gdy następnego dnia fotografowali owe plakaty wzbudzające swą treścią oburzenie przechodniów. Sprawcy umieszczający swe wynurzenia o rzekomych polskich obozach w zagranicznej prasie znajdują się faktycznie poza zasięgiem polskiego wymiaru sprawiedliwości, czego nie zmieni dodanie w systemie polskiego prawa karnego nowego w swej werbalnej stylistyce przepisu.

Projekt z 2016 r. przewidujący dodanie w ustawie o IPN art. 55a stał się prawem obowiązującym $\mathrm{w}$ drodze nowelizacji z 26.01.2018 r. z uzasadnieniem, z którego wynika, iż ustawodawca zignorował przedstawioną powyżej wykładnię, według której publiczne wypowiedzi nazywające niemieckie obozy w okupowanej Polsce „polskimi” są od 20 lat penalizowane jako zawierające zaprzeczanie zbrodniom nazistowskim w rozumieniu art. 55 tej ustawy. Nowo dodany przepis stanowił w ust. 1, że każdy, „kto publicznie i wbrew faktom przypisuje Narodowi Polskiemu lub Państwu Polskiemu odpowiedzialność lub współodpowiedzialność za popełnione przez III Rzeszę Niemiecką zbrodnie nazistowskie (...) lub za inne przestępstwa stanowiące zbrodnie przeciwko pokojowi, ludzkości lub zbrodnie wojenne lub w inny sposób rażąco pomniejsza odpowiedzialność rzeczywistych sprawców tych zbrodni, podlega grzywnie lub karze pozbawienia wolności do lat 3". Uzasadnienie nowelizacji wskazywało, 
że celem tego przepisu jest ochrona polskiej godności narodowej, co wynikało ze stwierdzenia: „od wielu lat w obiegu publicznym, także za granicą, pojawiają się określenia takie jak ,polskie obozy śmierci”, „polskie obozy koncentracyjne" (...). Nie ulega wątpliwości, że tego typu wypowiedzi sprzeczne z prawdą historyczną wywołują doniosłe skutki, godząc bezpośrednio w dobre imię Rzeczypospolitej Polskiej i Narodu Polskiego zwłaszcza za granicą. Powodują one bowiem u odbiorców wrażenie, że odpowiedzialność za popełnienie zbrodni III Rzeszy Niemieckiej ponosi Naród Polski i Państwo Polskie.” Z tego względu w art. 55b ustanowiona została karalność zachowań obywatela polskiego oraz cudzoziemca „niezależnie od przepisów obowiązujących w miejscu popełnienia przestępstw, o których mowa $\mathrm{w}$ art. $55 \mathrm{i}$ art. 55a".

Nowo dodany przepis wywołał za granicą zwielokrotniony „efekt bumerangowy” w tym sensie, że określenia ,polskie obozy koncentracyjne”, „polskie obozy śmierci" były multiplikowane w kontekście wątpliwości, co do zakresu kryminalizacji wypowiedzi, także innych aniżeli cytowane w uzasadnieniu. Obawy budziło m.in. zdanie uzasadnienia, w którym napisano: „w art. 55a ustawy o IPN proponuje się poszerzyć pole kryminalizacji o podobne czyny popełnione nieumyślnie”. Karalność „za nieumyślne czyny podobne” oznacza w istocie stosowanie analogii iuris, co samo w sobie pozostaje w sprzeczności z zasadą nullum crimen sine lege certa. Powstało przeto pytanie, czy ustawodawca „zadekretował historyczną prawdę", na której opiera się godność polskiego narodu i państwa, grożąc karą kryminalną za wszelkie wypowiedzi, które by tej godności uchybiały. Dla skrócenia wywodu przedstawiającego powstające wątpliwości zapytać można, czy karalną miałaby stać się publiczna wypowiedź o tym, że „w niemieckim obozie zagłady Auschwitz-Birkenau zamordowani zostali Żydzi, z których jakaś część trafiła tam, bo została zadenuncjowana przez Polaków". Pytanie to odnosi się w szczególności do wypowiedzi opartych na relacjach często nieżyjących już naocznych świadków zbrodni nazistowskich, których relacje zostały przez nich przedstawione swym zstępnym w ramach ,spadku pamięci”, a ci, którzy je zapamiętali i współcześnie powtarzają rodzinny przekaz, są przekonani, że głoszą prawdę. Chodzi więc o to, czy nowelizacja respektowała, czy przeciwnie - limitowała prawo do pamięci członków ofiar zbrodni nazistowskich, która jest częścią pamięci kolektywnej współczesnych społeczeństw.

$\mathrm{W}$ art. 55a ust. 1 ustawy o IPN, opisane zostały trzy postacie czynu zabronionego, tj. (po pierwsze) przypisywanie polskiemu narodowi lub państwu zbrodni nazistowskich, dalej (po drugie) przypisywanie innych zbrodni przeciwko pokojowi, ludzkości lub zbrodni wojennych, oraz (po trzecie) rażące pomniejszanie odpowiedzialności rzeczywistych sprawców tych zbrodni. Druga postać nowego przestępstwa nie została w uzasadnieniu projektu nowelizacji zilustrowana przykładami wypowiedzi realizującymi jej znamiona. Powstawało przeto pytanie, czy 
wypowiedź o powojennych „polskich obozach koncentracyjnych dla Niemców” może być uznana za realizującą znamiona przypisywania narodowi lub państwu odpowiedzialności lub współodpowiedzialności za inne aniżeli nazistowskie zbrodnie przeciwko ludzkości. Oznaczałoby to karalność na podstawie nowego przepisu wypowiedzi, które jeżeli pozostają oderwane od faktów, kwalifikowane są jako znieważenie narodu lub państwa polskiego w rozumieniu art. $133 \mathrm{KK}$, co zostało przedstawione w powyższym wywodzie.

Ustawodawca zadeklarował $\mathrm{w}$ art. 55a ust 3 o IPN, że bezprawność zarówno umyślnego, jak również nieumyślnego zachowania zostaje uchylona w dwóch szczególnych sytuacjach: ,nie popełnia przestępstwa sprawca czynu zabronionego określonego w ust. 1 i 2 , jeżeli dopuścił się tego czynu w ramach działalności artystycznej lub naukowej" (art. 55a ust. 3). W uzasadnieniu przytoczonego przepisu napisano: ,przewidziana tu konstrukcja kontratypu w znacznej mierze recypuje rozwiązanie funkcjonujące obecnie w art. $256 \S 3$ Kodeksu karnego odnośnie do sprawców przestępstwa publicznego propagowania ustroju faszystowskiego lub innego totalitarnego...”. Nazwanie „konstrukcją kontratypu” tego, co zostało napisane w cytowanym art. 55 ust. 3 ustawy o IPN budzi zdumienie ze względu na utrwalone w doktrynie i orzecznictwie rozumienie pojęcia „kontratyp”. Terminem tym określa się przypadki, w których ustawodawca stanowi, że nie popełnia przestępstwa ten, kto atakując dobro prawne zrealizował wszystkie znamiona tworzące typ czynu zabronionego, a pomimo to jego zachowanie nie jest przestępstwem ze względu na ustawowe dozwolenie na społecznie opłacalne naruszenie tego dobra, pozostającego w nie dającej się w inny sposób rozwiązać kolizji z drugim dobrem prawnie chronionym. Odniesienie takiego rozumienia kontratypu do konstrukcji zawartej w art. 55 ust. 3 u. o IPN prowadzi do wniosku, że sprawca, który realizuje umyślnie lub nieumyślnie zespół znamion czynu zabronionego, tj. „publicznie i wbrew faktom" głosi treści przypisujące polskiemu narodowi lub państwu zbrodnie nazistowskie lub inne, „nie popełnia przestępstwa”, jeżeli dopuścił się tego czynu w ramach prowadzonej przez siebie „działalności artystycznej lub naukowej”. Rozumieć można, że ustawodawca wyraził w ten sposób swe przekonanie, że działalność artystyczna, a także naukowa, uprawnia zarówno do świadomego głoszenia historycznej nieprawdy, hańbiącej współcześnie naród lub państwo polskie, jak również do fałszywych twierdzeń wynikających z niedbalstwa. Pojęcie kontratypu działalności artystycznej rodzi m.in. pytanie, czy miałby on wyłączać bezprawność także happeningów, w rodzaju słynnego „marszu osłów” ulicami Hamburga. ${ }^{71}$

71 Prawicowi ekstremiści zorganizowali w 1978 r. demonstrację, której uczestnicy nosili maski przedstawiające głowy osłów i zawieszone na szyjach szyldy z napisami głoszącymi ,ja osioł wierzę ciągle, że w niemieckich obozach koncentracyjnych »gazowano « Żydów”, ,ja osioł wierzę w kłamstwo o gazowaniu...", ,ja osioł wierzę stale w kłamstwa propagandowe zwycięskich mocarstw". 
Zakaz głoszenia umyślnie nieprawdy, jak i fałszu wynikającego z lekkomyślności lub niedbalstwa jest podstawowym kanonem działalności naukowej, który czyni dogmatycznie niezrozumiałą „,konstrukcję kontratypu” w ustawie o IPN. Projektodawca nowelizacji chyba nie dostrzegł sprzeczności pomiędzy swym rozumieniem kontratypu „działalności naukowej” a przedstawionym przez siebie uzasadnieniem karalności nieumyślnego działania: „obowiązek zachowania wymaganej w danych okolicznościach ostrożności oraz przewidywania konsekwencji posługiwania się nieprawdziwymi stwierdzeniami wyznaczają standardy właściwe dla publikacji w publicznych mediach i publikacji naukowych".

Koncepcja wszechświatowej ochrony polskiej godności narodowej zrealizowana w przedstawiony powyżej sposób musiała spotkać się ze sprzeciwem ze względu na wynikające z niej zagrożenia dla dobra prawnego, jakim jest pamięć kolektywna współczesnych społeczeństw. Zastrzeżenia do nowych przepisów karnych ustawy o IPN oraz bieg zdarzeń natury politycznej relacjonowała prasa krajowa i światowa, co pozwala uznać, że są one powszechnie znane i nie ma w tym miejscu potrzeby ich przedstawiania. Podnieść jednakże trzeba, że kryminalizacja zachowań, które już od dawna są spenalizowane musiała wywołać uzasadnione obawy, czy intencją ustawodawcy jest poddanie prokuratorskiej kontroli wypowiedzi opartych na prawie do pamięci indywidualnej i zbiorowej o tym wszystkim, co stało się Polsce w okresie niemieckiej okupacji. Krytyka doprowadziła do tego, że polski ustawodawca zreflektował się uchylając art. 55a i art. 55b ustawy o IPN, w kolejnej nowelizacji z 27.06.2018 r. Przywrócony został zatem stan prawny, w którym polska godność narodowa chroniona jest przez art. $133 \mathrm{KK}$, zakazujący publicznego znieważania narodu i państwa, oraz art. 55 ustawy o IPN, penalizujący publiczne kłamanie o Auschwitz.

\section{WNIOSKI KOŃCOWE}

Podsumowanie rozważań rozpocząć należy od zwrócenia uwagi na to, że w obowiązującym włoskim prawie karnym nie ma już przestępstwa opisywanego w art. $291 \mathrm{KK}$ z 1930 r. jako znieważenie narodu włoskiego, który to przepis - jak podano na wstępie - posłużył J. Makarewiczowi za wzór dla art. 152 KK z 1932 r., opisującego czyn tego, „kto publicznie lży lub wyszydza” naród polski. Depenalizacja zachowania stanowiącego „zniewagę narodu włoskiego" (vilipendio alla nazione italiana) nastąpiła w 2016 r. z równoczesnym zagrożeniem tylko sankcją administracyjną ${ }^{72}$. W systemie polskiego prawa nie byłoby racjonalne wykreślenie przestępstwa opisanego w art. 133 KK czy też przeniesienie

${ }^{72}$ Rozporządzenie z mocą ustawy z 15.01.2016 r. nr 7 i 8, „Gazzetta Ufficiale” nr 17 z 22.01.2016 r. 
czynu zabronionego znieważenia narodu do kategorii wykroczeń. Wykreślenie z KK tego przepisu mogłoby się dokonać w następstwie uznania go za sprzeczny z Konstytucją, do czego brak jest dogmatycznych podstaw, jeżeli przyjąć, że przedmiotem ochrony jest dobro prawne opierające swą normatywną egzystencję na pamięci zbiorowej polskiego społeczeństwa. W praktyce sądowej nie znajdujemy wyroków wypaczających zakaz ustanowiony w art. $133 \mathrm{KK}$, które stanowiłyby ograniczenia wolności publicznego wyrażania przekonań.

Podnieść przy tym trzeba, że pamięć zbiorowa nakazuje współcześnie dokonywanie ocen w kategoriach znieważenia narodu polskiego, pojawiających się w Internecie wypowiedzi, odwołujących się w przerażający sposób właśnie do tego, co musi pozostawać pod ochroną prawa. Oto bowiem na stronie internetowej Facebook, „poświęconej rozrywce”, umieszczono powszechnie znane i zapamiętane jako symbol nazistowskiego ludobójstwa zdjęcie przedstawiające tory kolejowe i bramę obozu zagłady Auschwitz-Birkenau z podpisem: „Nie rozumiem, dlaczego nie chcemy przyjąć do Polski muzułmanów. Przecież infrastrukturę już mamy." Zanim zdjęcie to zostało usunięte prawie 5.000 Polaków z kraju i zagranicy zdeklarowało „like”. Część z nich umieściła to zdjęcie na własnych stronach internetowych i dodała w komentarze w rodzaju „Muslim people, welcome to Poland - we are sooo ready". Prokuratura Rejonowa Wrocław Fabryczna wszczęła 07.08.2015 r. śledztwo w tej sprawie uznając, że miało miejsce publiczne nawoływanie do stosowania przemocy z powodu przynależności religijnej innych osób (art. 126a KK). Zauważyć jednakże trzeba, że dokonane zostało równoczesne publiczne znieważenie narodu polskiego, o ciężarze co najmniej równym cynicznemu użyciu określenia „polski obóz koncentracyjny Auschwitz”. Jako podstawę kwalifikacji tego rodzaju wynurzeń przyjąć przeto należy oba przepisy pozostające w rzeczywistym zbiegu (art. 126a i art. $133 \mathrm{KK}$ ), gdyż dopiero łącznie oddają one rozmiar dokonanego bezprawia.

Skonstatować także trzeba, że nie wymaga zmiany zakres kryminalizacji „kłamstwa o Auschwitz”. Zarówno art. 133 KK jak również art. 55 ustawy o IPN współtworzą prawo karne pamięci i jako takie mają swe uzasadnienie w historii oraz współczesnej aksjologii prawa. Podnieść wreszcie należy, że nieuzasadnione jako bezwzględnie konieczne zmiany w prawie karnym, pojmowanym jako ultima ratio, mogą same w sobie stanowić zagrożenie dla „godności prawa”, a prowadząc do jego destrukcji, dewaluują wartość dóbr prawych, które mają chronićp ${ }^{73}$.

Na zakończenie podnieść trzeba, że Polska godność narodowa jako dobro prawne wymaga dziś ochrony przed publicznie głoszonymi hasłami w rodzaju

${ }^{73}$ A. Kojder, Godność i siła prawa, Warszawa 2001, s. 17. Obowiązujące przez pięć miesięcy 2018 r. przepisy art. 55a i art. 55b ustawy o IPN uznać należy za swego rodzaju ,wybryk ustawodawcy". 
„Europa biała albo bezludna”, „Murzyn nie może być Polakiem”, jeżeli pamiętać, że stanowią one wyraz perwersyjnego manifestowania wyższości „rasy aryjskiej”, które w wersji przyjętej przez ideologię narodowego socjalizmu w III Rzeszy zapisane zostało na czarnych kartach historii ${ }^{74}$.

\title{
POLISH NATIONAL DIGNITY IN LIGHT OF CRIMINAL LAW
}

\begin{abstract}
Poland is contemporarily the only country in Europe where the law includes criminal liability for publically defaming the nation or for being disrespectful towards it. This makes the national dignity an independent legal interest. Consequently, it seems worthwhile to pay attention to the origins of the regulations which protect this particular legal interest which were introduced into the Polish law in 1932. Moreover, it creates the need for a commentary on the statutory description of the acts which break the law. It also necessitates the portrayal of the issues created on the grounds of the practical application of the sanctionative norms in the modern world. Historical roots are the reason behind the way national dignity is currently perceived and felt. Furthermore, the historical experiences determine the direction of the interpretation of the applicable law which protects the nation's dignity. To put it in other words, the present-day interpretation of the penal norms is based on public history and as such it constitutes the historical interpretation which leads to a prescriptive understanding of the semantics of these terms. The aforementioned contemporary interpretation seeks to answer the question what type of behaviour is characterised by the perpetration of "disrespect". Furthermore, it aims to answer which acts can be defined as a show of contempt which is equal to "defaming" the Polish nation. Consequently, the objective of the following article is to look at the contemporary law through the historically determined prism of symbolic criminalization of behaviours which attack Polish national dignity as well as to give examples of modern incriminating public statements. The provisions of criminal law which stipulate criminal liability for public defamation and disrespecting the nation have not changed since it was introduced into the Polish law. Despite this fact, the current assessment of behaviour as a violation of the nation's dignity is influenced by the tragic $20^{\text {th }}$-century history and its memory as a legal interest. In the course of the study of the specific instances of behaviour which were not anticipated by the pre-war legislator, one needs to attempt to point to the reasons behind preserving their punishability.
\end{abstract}

${ }^{74}$ Hitler wywodził, „, z Murzyna ani Chińczyka nie będzie Germanina”, choćby nauczyli się oni języka niemieckiego. Mein Kampf..., s. 428. Według A. Rosenberga kobieta zadająca się z Murzynem lub Żydem miała być pozbawiona niemieckiego obywatelstwa, co dotyczyć miało także jej dzieci. Der Mythus des zwanzigsten Jahrhunderts. Eine Wertung der seelisch - geistigen Gestaltenkämpfe unserer Zeit, München 1933, s. 579, 595. Według projektu zmiany ustawy o ochronie Republiki z 13.03.1930 r. karze ciężkiego więzienia albo karze śmierci miał podlegać ten, „kto przez wymieszanie z członkami żydowskiej wspólnoty krwi lub kolorowymi rasami przyczynia się lub grozi przyczynieniem do rasowego pogorszenia lub zniszczenia niemieckiego narodu". Szerzej: W. Kulesza, Swastyka w świetle prawa karnego..., s. 89-90. 


\section{LA DIGNITÉ NATIONALE POLONAISE À LA LUMIÈRE DU DROIT PÉNAL}

\section{Résumé}

La Pologne est actuellement le seul État en Europe dont le droit prévoit une responsabilité pénale pour avoir publiquement insulté la nation ou pour avoir montré un manque de respect, ce qui fait de la dignité nationale un bien juridique autonome. Il est donc important d'évoquer la genèse des lois qui protègent ce bien juridique, introduites dans le droit polonais en 1932. Il faut aussi formuler un commentaire sur la description statutaire des actes y portant atteinte, ainsi que présenter les problèmes découlant de l'application pratique des normes de sanction dans la réalité actuelle. Le fait est que le sentiment actuel de la dignité nationale est enraciné dans le passé et c'est justement cette expérience historique indique la direction de l'interprétation des dispositions de la loi applicable, protégeant la dignité de la nation. En d'autres termes, l'interprétation actuelle des normes de droit pénal visant à répondre à la question quels comportements portent la marque du «manque de respect» ou du mépris qui «insulte» la nation polonaise est basée sur la mémoire collective et en tant que telle constitue une interprétation historique menant à la compréhension de la sémantique normative de ces notions.

Le but de l'article est donc d'examiner la jurisprudence contemporaine à travers le prisme de la criminalisation symbolique, historiquement déterminée, des comportements attaquant la dignité nationale polonaise et de donner des exemples de déclarations publiques actuellement incriminées. Bien que les dispositions du droit pénal établissant la responsabilité pénale pour avoir publiquement insulté et méprisé la nation n'aient pas changé depuis leur introduction dans l'ordre juridique polonais, néanmoins, l'histoire tragique du XXème siècle et sa mémoire influencent l'évaluation contemporaine de comportements liés à la violation de la dignité nationale en tant que bien juridique. Lors de l'examen de tels comportements particuliers, imprévisibles pour le législateur d'avant-guerre, il faut tenter d'indiquer les raisons du maintien de la responsabilité pénale. 